\title{
Hydrochemistry Characteristics and Water Quality Assessment for Irrigation along the Second Songhua River in the South of the Songnen Plain, Northeast China
}

\author{
Sun Xiaoqing ${ }^{1,2}$, Bian Jianmin ${ }^{1,2}$, Zhang Chunpeng ${ }^{1,2}$, \\ Wang Yu ${ }^{1,2 *}$, Wan Hanli ${ }^{1,2}$, Jia Zhuo ${ }^{1,2}$ \\ ${ }^{1}$ College of New Energy and Environment, Jilin University, Changchun, Jilin Province, China \\ ${ }^{2}$ Key Laboratory of Groundwater Resources and Environment (Jilin University), Ministry of Education, \\ Jilin University, Changchun, Jilin Province, China
}

Received: 17 November 2018

Accepted: 19 January 2019

\begin{abstract}
In view of changes in the water environment in Songnen Plain and water quality problems in recent years, the Second Songhua River Basin was used as our research object. To conduct the water environment investigations, 11 surface water samples and 76 shallow groundwater samples were collected. Multiple methods, such as isotope hydrological analysis, principal component analysis, and irrigation water quality parameter (SSP, SAR, RSC, MAR, KR) analysis were used to systematically apply water chemistry analysis and its evolutionary process, and water quality evaluation for irrigation. The results showed that $\mathrm{Ca}^{2+}$ and $\mathrm{HCO}_{3}^{-}$were the main ions in the water body. The regional groundwater was recharged by atmospheric precipitation, and the surface water received both atmospheric precipitation and groundwater recharge. The hydrogeological process included the weathering and dissolution of carbonates, and the ion exchange reaction. In addition, the major reaction of local groundwater was the weathering and dissolution of silicate. Water quality was affected by agricultural fertilizer and domestic sewage. The water downstream of the basin, if used for irrigation, might accelerate the formation of alkaline and saline soil, neither of which help crop growth. The water upstream of the watershed in the region was suitable for irrigation.
\end{abstract}

Keywords: chemical information of water, statistical analysis, isotope hydrology, assessment of irrigation water 


\section{Introduction}

Surface water and groundwater are the main water resources on earth. The interaction between the two affects the chemical components of the water and records the formation, transformation, and migration of water bodies under the action of human activities to a certain degree [1-4]. The mutual conversion of surface water and groundwater is a hotspot of research in the field of terrestrial water circulation and water resources [5-7]. Understanding the interaction between surface water and groundwater is critical for the management of water resources [8] and analysis of ecohydrology [9]. In irrigated areas, surface water and groundwater flows become more complicated with the impacts of surface water diversion, groundwater pumping and irrigation [10]. This plays a decisive role in basin water recontradiction between the supply and demand of water resources, and basin ecological environment source evaluation, scientific management of development and utilization, relieving construction.

The sustainability of irrigated agriculture in many arid and semiarid areas of the world is at risk because of a combination of several interrelated factors, including a lack of fresh water, lack of drainage, the presence of high water tables, and salinization of soil and groundwater resources [11]. Water transfer projects have been launched across the globe to alleviate water shortage problems in arid regions and promote development, such as in Australia, the United States, Canada, China, and India [12]. In the study area, the river-lake connectivity project has been carried out since 2015, aimed at improving the state of the environment, and the connected surface water will be referenced for irrigation in agricultural areas. In order to avoid the occurrence and deterioration of such problems, it is necessary to evaluate the applicability of irrigation water resources.

Songnen Plain is located in the central part of the northeastern Plain, which is one of the main bases for grain production and animal husbandry, and one of the three major plains in northeastern China [13]. In recent years, the rapid expansion of urban areas, the increasing scale of industry, and the increase of the area of paddy fields along the mainstream of the Songhua River have resulted in a continuous increase in the demand for water resources. With the current amount of exploitation and utilization, water quality is a concern [14-15]. The contribution to the total amount of sewage in the Songhua River system is about $30 \%$, and the pollution effect coefficient for the Songhua River basin is about 0.4 [15]. For example, excessive pumping of groundwater will bring about runoff from the river and floodplains toward over-exploited areas, which could result in abnormal hydro-chemical conditions. Furthermore, the toxic substances from agricultural irrigation and fertilization would infiltrate the groundwater together with the runoff, threatening the safety of drinking groundwater. The water quality for the downstream of the second Songhua River, for example, from the water quality of the Linjiang Bridge has been classified as Category III. The impact factor was the potassium and permanganate index, and occasionally mercury exceeded the standard. The water quality for the monitoring section of Zhenjiangkou and Songhuajiang Village has reached Grade V. The over-standard items were the chemical oxygen demand, ammonia nitrogen, $\mathrm{BOD}_{5}$, petroleum, and so forth. The water quality of the Yinma River has been evaluated as Grade V. The major pollutants were chemical requirements, volatile phenols, and oils [16-18].

According to the environmental functions and protection objectives of surface waters, they are divided into five categories according to the level of function.

Class I water is mainly used in source water and national nature reserves.

Class II water is mainly used in the first-grade protection zone of centralized drinking water surface water sources, cherished aquatic habitats, fish and shrimp spawning grounds, and feeding grounds for juveniles and young fish.

Class III water is mainly used in the secondary protection areas of centralized drinking water surface water sources, fish and shrimp wintering fields, migratory passages, aquaculture areas, and other fishery waters and swimming areas.

Class IV water is mainly suitable for general industrial water areas and recreational water areas where the human body is not in direct contact with the water.

Class V water is mainly used in general agricultural water areas and general landscape waters.

The study of the water chemical information of the interaction between the unconfined groundwater and surface water is the basis for understanding water quality degradation. In order to solve the above problems, 11 surface water and 76 groundwater samples of the Second Songhua River were collected in 2012-2014. The hydro-chemical concentrations and chemical properties of the surface water and groundwater in the area were characterized via SPSS 17.0 in this paper. The particular purpose of this study is to (1) understand the relationship between the surface water and unconfined groundwater with the aid of isotope hydrology; (2) discuss the hydro-chemical evolution of the surface water and unconfined groundwater; and (3) assess the quality of the surface water and groundwater in the district for irrigation functions.

\section{Study Area}

\section{Study Site Description}

The study area is located in the southern part of Songnen Plain $\left(121^{\circ} 27^{\prime}-128^{\circ} 12^{\prime} \mathrm{E}, \quad 43^{\circ} 36^{\prime}-49^{\circ} 45^{\prime} \mathrm{N}\right)$ in northeastern China (Fig. 1c). The study area has the Changbai Mountains in the east, the Daxingan 
(Greater Khingan) Mountains in the west, and the Songliao watershed divide in the south. The total area includes Jilin Province and Inner Mongolia Province in the district. The research region has a semi-humid and semi-arid continental monsoon climate. The mean annual precipitation is $350-600 \mathrm{~mm}$, with $70-80 \%$ of precipitation occurring during June to September. The average annual temperature is about $4 \cdot 0-5.5^{\circ} \mathrm{C}$. The
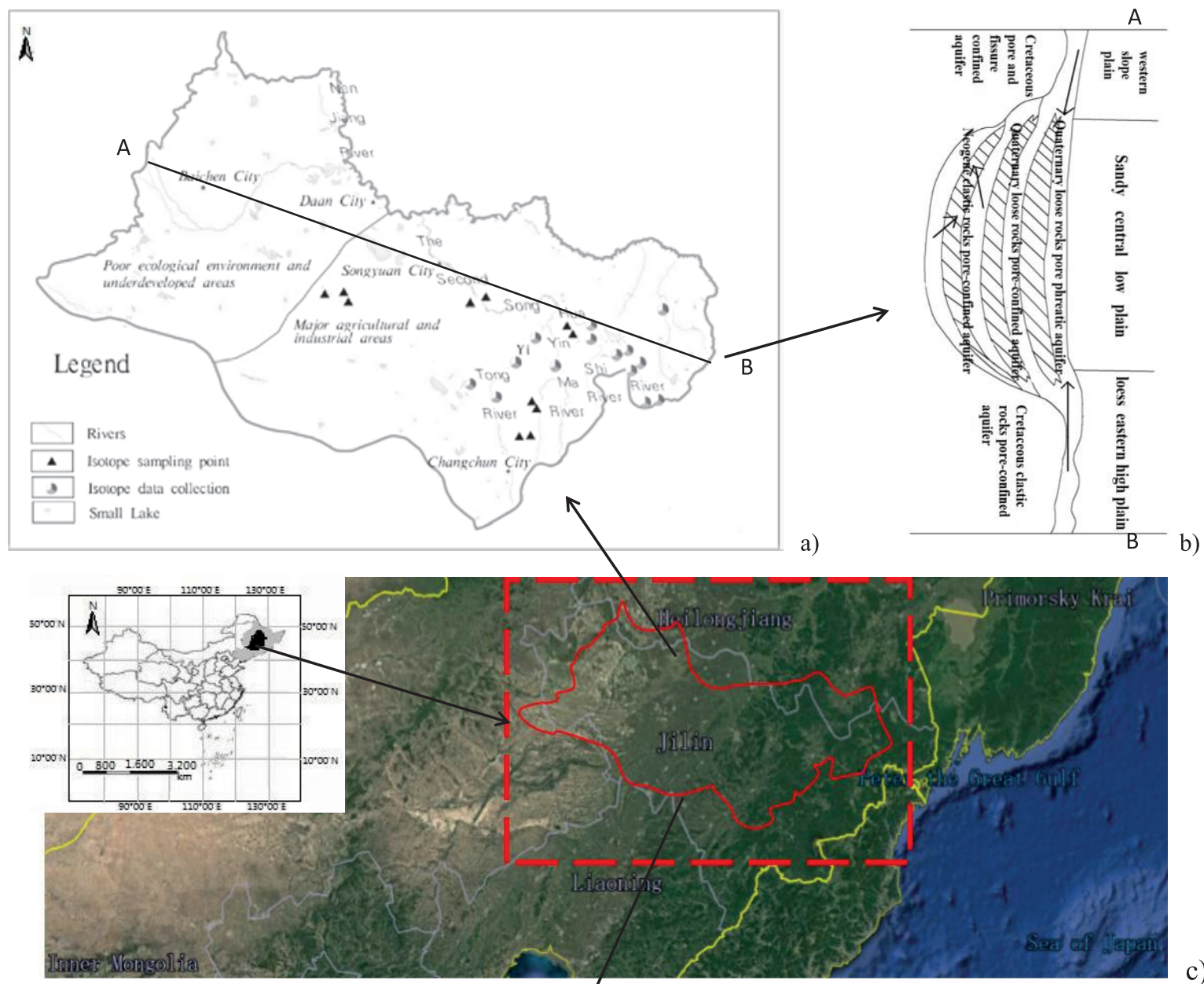

c)

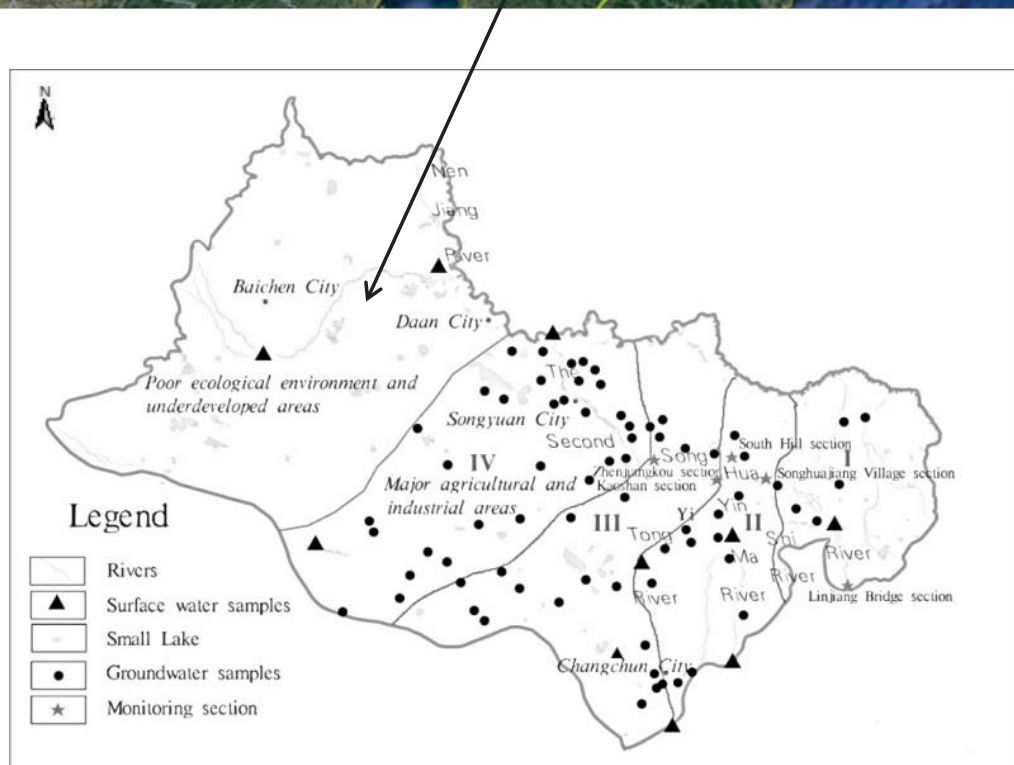

d)

Fig. 1. Groundwater and surface water isotope sampling sites and collection data in the study area (a). Hydrogeological profile (b). The location of the study area (c). The water sampling sites and surface water system (d). To the west of the dividing line, near Da'an city on the map, is the western part of Jilin Province. The ecological environment is harsh, and the climate is dry. To the east, mainly showing the area along the Second Songhua River, agriculture is developed and the climate is semi-humid and semi-arid. 
average temperature in January is -16 to $-26^{\circ} \mathrm{C}$, while the average temperature in July is $21-23^{\circ} \mathrm{C}$. Evaporation from the water surface is between 700 and $1100 \mathrm{~mm}$.

The Second Songhua River has a total length of 790 kilometers and an area of approximately $7.8 \mathrm{~km}^{2}$, which accounts for $14 \%$ of the basin. The Songhua River has two sources, the north and the south. The northern source originates from the Nenjiang River. The southern source originates from the Tianchi of Changbai Mountain. The Second Songhua (the southern source river), which flows from southeast to northwest, and the Nenjiang merge in the center of the area and then become the Songhua, which flows from west to east. It is the main commodity grain production area and industrial area in the three northeastern provinces. The Yitong and Yinma rivers in the south of the central low plain, and the Taoer and Huolin rivers in the slope plain in the west, are the Ersong tributaries in the study area. The surface water system distribution of the basin in the area is shown in Fig. 1d).

In Fig. 1d), three monitoring sections can be seen located in the main stream of the Second Songhua, and one further section lies in the branch (the merged site of the Yitong and Yinma rivers). These monitoring sections are Songhuajiang Village, South Hill, Kaoshan Bridge, and Zhenjiangkou section. The four water quality monitoring sections divide the surface river into four areas along the direction of the flow, upstream (above the South Hill section), tributaries (including the Yinma and Yitong rivers), and downstream (below the Zhenjiangkou section) of the main stream. The corresponding four aquifer sub-areas are also formed: I, II, III, and IV (Fig. 1d).

According to Fig. 1d), a boundary shows up, the west area has a poor environmental state, while the major agriculture and industry developments are distributed in the east. One of the purposes of this study is to judge whether the water resources in the research region are suitable for irrigation water; therefore, the groundwater sampling points in the agricultural developed areas are relatively dense.

A comparative analysis of the use of pesticides and fertilizers in the study area from 2008-2012 showed that the use of agricultural fertilizers increased year by year, from $2,890,040$ tons in 2008 to $3,430,422$ tons in 2012 , indicating that in recent years, with the increase of agricultural output in the region, the application rate of chemical fertilizers and pesticides also increased. Due to their extensive use in the region, some of them infiltrated into the soil and groundwater with rainfall, thereby affecting the groundwater environment. Table 1 shows the area distribution of various land types in the six administrative regions of the study area in 2010.

\section{Geology and Hydro-Geology}

The study area is underlain by alluvial, lacustrine, and aeolian deposits. Under the control of neotectonic movements and geomorphological conditions, the Quaternary strata of the study area formed obvious differences between the western slope plain, the central low plain, and the eastern high plain (Fig. 1b). In the western slope plain, there are more depositional features of the internal structure, mainly ice water accumulation and flood alluvium, and the lithology is mostly coarsegrained sandy soil which is thinning from east to west. In the lower central plain, the lower Pleistocene river and lake gravelly soil, the Middle Pleistocene lake-phase cohesive soil, and the Upper Pleistocene river-lacustrine sandy soil are generally piled up. The overlying Holocene sediments are more common mainly aeolian deposits and fluvial deposits - and the swampy deposits are distributed like dots. In the high plains of eastern China, the neotectonic movement takes a block-like elevation south of the South Songhua River, and is dominated by the alluvial loess in the middle and upper Pleistocene and the subtropical clay in Chonghu Lake [7, 13, 16-18].

Songnen Plain is a large-scale underground water collection basin. It is a complete groundwater flow system consisting of Tertiary Eocene, the Oligocene Yi'an Formation, the Miocene Da'an Formation, the Pliocene Taikang Formation, and the Lower Pleistocene. Since Songnen Plain is also a basin containing multiple aquifers, each aquifer has its own relatively independent water flow system. Therefore, shallow water, middle water, and deep groundwater flow systems that are related to each other and relatively independent are

Table 1. Land use in various regions of the study area in $2010\left(\mathrm{~km}^{2}\right)$.

\begin{tabular}{|c|c|c|c|c|c|c|}
\hline Cities & Cultivate land & Woodland & Grassland & Building Site & Unused Land & Total \\
\hline Songyuan & 9147 & 2934 & 6175 & 896 & 871 & 20023 \\
\hline Baicheng & 9473 & 3065 & 7362 & 409 & 841 & 21150 \\
\hline Changchun & 9815 & 899 & 3779 & 1668 & 109 & 16270 \\
\hline Jilin & 363 & 331 & 128 & 63 & 0 & 885 \\
\hline Siping & 1057 & 0 & 46 & 113 & 0 & 1216 \\
\hline Neimeng & & & & & & 2685 \\
\hline Total & 29855 & 7229 & 17490 & 3149 & 1821 & 62229 \\
\hline
\end{tabular}


formed on the section. The overall flow of groundwater in the basin converges from the recharge area on both the western and eastern sides to the discharge center of the basin, and finally flows out of the basin through Songnen River and the subsurface flow of the valley. In this study, we mainly focus on shallow groundwater aquifers.

Due to the uplift belt in the east of the study area, a loess-like undulating high plain and a sandy wavy high plain are formed, and a local clay soil underlies a thin layer of gravel. The aquifer is mainly composed of pore phreatic aquifer, pore-confined aquifer, and inter layer confined aquifer. The groundwater depth is $5 \sim 30 \mathrm{~m}$. The central low plain has the characteristics of a basin, and it has accumulated thick Cretaceous and Tertiary clastic rocks and thick Quaternary loose sediments. The terrain is low and the permeability in the aerated zone is good. The groundwater level is less than $10 \mathrm{~m}$, the main distribution is confined aquifer, and the pore phreatic aquifer is locally distributed. In the western mountain front sloping plain, sand-gravel fan-shaped land also constitutes a very water-rich storage structure. The main part is pore phreatic aquifer, and the water depth is less than $5 \mathrm{~m}$.

\section{Material and Methods}

\section{Water Sampling and Analysis}

To achieve this paper's objectives, 11 surface water and 76 shallow groundwater (depth $<30 \mathrm{~m}$ ) samples, 11 surface water and 11 groundwater isotopic samples were collected between July and August in 2012-2014 (Fig. 1a), and tested in the laboratory of the Heilongjiang Province Hydro-Geology and Environmental Geology Investigation Institute. The location of the sampling points is illustrated in Fig. 1a), d). Field test indicators include water temperature, $\mathrm{pH}, \mathrm{EC}$, Eh, DO, and turbidity. The laboratory test index includes TH, TDS, $\mathrm{Ca}^{2+}, \mathrm{Mg}^{2+}, \mathrm{K}^{+}, \mathrm{Na}^{+}, \mathrm{Cl}^{-}, \mathrm{SO}_{4}{ }^{2-}, \mathrm{HCO}_{3}^{-}, \mathrm{NO}_{3}^{-}, \mathrm{NO}_{2}^{-}, \mathrm{F}-$, $\mathrm{SiO}_{2}, \mathrm{Cu}, \mathrm{Mn}, \mathrm{Zn}, \mathrm{As}, \mathrm{Pb}, \mathrm{Cd}, \mathrm{TCr}, \mathrm{Al}, \mathrm{I}^{-}, \mathrm{Fe}, \mathrm{DBS}$, and $\mathrm{COD}_{\mathrm{Mn}}$.

The samples were collected in $500 \mathrm{ml}$ sterilized polythene bottles. Each bottle was rinsed with distilled water before pouring in the sample water. The bottles were labeled and airtight. On the field, the latitude and longitude of each sampling point were taken with GPS, and the approximate depth of the wells was noted from the well owner's records. For all samples collected, parameters such as $\mathrm{pH}$, electrical conductivity (EC), and total dissolved solids (TDS) were measured in the field. The electrical conductivity (EC), total dissolved solutes (TDS), $\mathrm{pH}$, and temperature for the rivers, hand-dug wells and boreholes were measured at each sampling point with a radiometer conductivity meter (PHM82) and a standard $\mathrm{pH}$ meter.

For the rivers, the water samples were collected from the middle of the rivers to ensure perfect mixing of the water. For sampling of the hand-dug wells, prior to sampling, each well was pumped for a few minutes until it purged out approximately twice the well volume, or until steady-state chemical conditions ( $\mathrm{pH}$, TDS, EC, salinity, and temperature) were obtained. The above was done to ensure that the sampled water from the hand-dug wells was from the casing or open wells, and the sampled water from the boreholes was from the aquifer. Water samples were collected in two separate polyethylene bottles in order to analyze for major ions

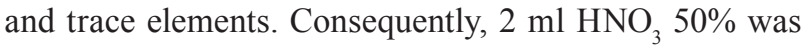
added into water samples for trace element analysis to preserve precipitation.

$\mathrm{K}^{+}$and $\mathrm{Na}^{+}$were tested using the flame photometric method; $\mathrm{Ca}^{2+}, \mathrm{Mg}^{2+}$, and total hardness were tested by the EDTA complex titration method; $\mathrm{Cl}^{-}$was tested by the standard solution titration with silver nitrate method; $\mathrm{pH}$ was tested by a $\mathrm{pH}$ meter; and $\mathrm{SiO}_{2}$ and anions such as $\mathrm{SO}_{4}{ }^{2-}$, and $\mathrm{F}^{-}, \mathrm{NO}_{3}^{-}$, and $\mathrm{NO}_{2}^{-}$were tested by the spectrophoto metric method. The concentrations of trace metals such as $\mathrm{Fe}$ and $\mathrm{Mn}$ were analyzed by atomic absorption. The concentrations of trace elements $\mathrm{Cu}$, $\mathrm{Zn}, \mathrm{As}, \mathrm{Pb}, \mathrm{Cd}, \mathrm{TCr}, \mathrm{Al}$, and $\mathrm{I}^{-}$were measured using inductively coupled plasma and mass spectrometry, which was linearly calibrated from 10 to $100 \mathrm{lg} / \mathrm{L}$ with custom multielement standards (SPEX CertiPrep, Inc., NJ, USA) before use. The concentrations of DBS and $\mathrm{COD}_{\mathrm{Mn}}$ were measured by the methylene blue spectrophotometric method and acid potassium permanganate method. The stable isotope $(\mathrm{d} 2 \mathrm{H}$ and $\mathrm{d} 18 \mathrm{O}$ ) compositions of the waters (rivers and handdug wells) were measured using a liquid-water stable isotope analyzer (based on off-axis integrated cavity output spectroscopy (OA-ICOS) via laser absorption). $\mathrm{D}$ and ${ }^{18} \mathrm{O}$ were tested by the Laboratory of Geographical Resources Institute of Geographic Sciences and Natural Resources Research, CAS. Quality assurance and quality control were conducted according to the "Standard for Assessment and Investigation of Groundwater Pollution" (DD2008-01), using the method of adding standard recovery and extracting repeated sampling to control quality.

Analysis accuracy was assessed through the ion balance error, which was found to be in the range of $\pm 5 \%$, indicating the accuracy and quality of the analytical data.

$$
B E=\left[\frac{(T C C-T C A)}{T C C+T C A}\right] \times 100
$$

Where TCC and TCA are the concentrations of total cations and total anions in meq $/ \mathrm{L}$, and $\mathrm{BE}$ denotes the percentage of ionic balance error.

\section{Data Analysis}

In this study, isotope hydrology, the Piper diagram, the principal component analysis method, the Gibbs plot, the CAI-1 index, and the assessment of water quality for 
irrigation with the aid of SSP (\%Na) [19], SAR (sodium absorption ratio) [20], RSC (residual sodium carbonate) [21], MAR (magnesium adsorption ratio) [22], and KR [19] were used.

The principal component analysis method, which reflects the characteristics of ion composition and ion proportion in water, was used in this paper to determine the geochemical process of groundwater. In the analysis, the principal component analysis method is further used to simplify the data structure and reduce indicators that have no indicative significance, while losing minimal data information. The original variables are converted into new principal components using orthogonal transformation, and there is no correlation between them as each principal component is a linear combination of partial raw variables. The exact principle component is such that the maximum variance is dedicated to the first component, the second greatest variance to the second component, and so on. To provide information based on the most meaningful parameters with minimum loss of the original information, the axes defined by PCA rotate, and new variables can be created. In this study, factor analysis alongside principle component analysis methods are put to use in the water quality assessment. There are two ways to determine the number of principal components, when the cumulative contribution rate of $\mathrm{K}$ principal components reaches a certain eigenvalue (generally $70 \%$ or more), the first $\mathrm{K}$ principal components are retained; the principal component with an eigenvalue $\geq 1$ is selected.

The soluble sodium percentage (SSP) is used to evaluate the sodium hazard [23]. Todd (1980) defined the soluble sodium percentage (SSP), or $\mathrm{Na} \%$, as follows:

$$
\operatorname{SSPorNa} \%=\frac{\left(\mathrm{Na}^{+}+\mathrm{K}^{+}\right) \cdot 100}{\left(\mathrm{Ca}^{2+}+\mathrm{Mg}^{2+}+N a^{+}+\mathrm{K}^{+}\right)}
$$

For evaluating water quality for irrigation purposes, the sodium or alkali hazard expressed by the sodium adsorption ratio (SAR) is widely used. If the water sample is high in $\mathrm{Na}+$ and low in $\mathrm{Ca}^{2+}$, the ion exchange complex may become saturated with $\mathrm{Na}+$, which destroys the soil structure [21]. The SAR value of irrigation water quantifies the relative proportion of $\mathrm{Na}+$ to $\mathrm{Ca}^{2+}$ and $\mathrm{Mg}^{2+}$, and is computed as follows:

$$
S A R=\frac{N a^{+}}{\sqrt{C a^{2+}+M g^{2+}} / 2}
$$

...where $\mathrm{Na}^{+}, \mathrm{Ca}_{2}^{+}$, and $\mathrm{Mg}_{2}^{+}$are defined as the concentrations of $\mathrm{Na}, \mathrm{Ca}$, and $\mathrm{Mg}$ ions in the water, respectively [23]. The residual sodium carbonate (RSC) is computed by taking the alkaline earths and weak acids, as follows:

$$
\mathrm{RSC}=\left(\mathrm{CO}_{3}{ }^{2-}+\mathrm{HCO}_{3}^{-}\right)-\left(\mathrm{Ca}^{2+}+\mathrm{Mg}^{2+}\right)
$$

The magnesium adsorption ratio (MAR), also known as the magnesium hazard (MH), was calculated as follows:

$$
M A R=\frac{M g^{2+} \cdot 100}{\left(C a^{2+}+M g^{2+}\right)}
$$

Lastly, Kelley's ratio (KR) [24] is described as follows:

$$
K R=\frac{\mathrm{Na}+}{\left(\mathrm{Ca}^{2+}+\mathrm{Mg}^{2+}\right)}
$$

All ionic concentrations are in the milli equivalent per liter (meq/L). All these parameters and individual chemical parameters had been compared with national and international standards in order to assess the groundwater suitability.

The Piper diagram is one of the most effective graphic representations in the study of groundwater quality, helping the understanding of the groundwater geochemical characteristics. In this paper, the water chemical analysis software AquaChem V4.0 was used to draw the Piper diagrams of the selected samples, which can directly reflect the general chemical characteristics of water samples and their relative contents. Major ion compositions (including $\mathrm{Ca}, \mathrm{Mg}, \mathrm{K}, \mathrm{Na}$, and $\mathrm{Cl}^{-}$, $\mathrm{SO}_{4}^{2-}$, and $\mathrm{HCO}_{3}^{-}$, the units of which are the milligram equivalent) were used to identify the water types with the help of the AquaChem software (version 4.0).

The mixing ratio of precipitation with surface water and groundwater during the rainy season was calculated using the multisource mass balance model [25]. For isotopic mass balance studies involving a twocomponent mixture, the fraction of surface water in the mixture is defined as:

$$
\begin{gathered}
Y G+Y P=Y M \\
Y G \delta G+Y P \delta P=Y M \delta M
\end{gathered}
$$

...where YG and YP are the percentage contribution of the groundwater and precipitation to the mixture YM. $\delta \mathrm{G}, \delta \mathrm{P}$, and $\delta \mathrm{M}$ are the isotopic compositions of the groundwater, precipitation and admixture, respectively. Substituting Equations (8) in (9) and (10) for YG and YP provides the contribution of the groundwater and precipitation component to the surface mixture.

$$
\begin{gathered}
Y G=Y M(\delta M-\delta P) /(\delta G-\delta P) \\
Y P=Y M(\delta G-\delta M) /(\delta P-\delta G)
\end{gathered}
$$

Differences in the isotopic composition of the surface water, rainfall, and groundwater result in relatively high precision for detecting the mixing proportion of groundwater in the surface water [26].

The index value of the CAI-1 (choro-alkaline index) [27] indicates whether the ion exchange between 
Table 2. Abbreviations that appear in the abstract and in the body of the article.

\begin{tabular}{|c|c|c|c|c|c|}
\hline Abbreviation & Full name & Abbreviation & Full name & Abbreviation & Full name \\
\hline SSP & $\begin{array}{c}\text { Soluble sodium } \\
\text { percentage or Na\% }\end{array}$ & DBS & $\begin{array}{c}\text { Sodium dodecyl } \\
\text { benzene sulfonate }\end{array}$ & DO & Dissolved oxygen \\
\hline SAR & $\begin{array}{c}\text { Sodium adsorption } \\
\text { ratio }\end{array}$ & TH & Total hardness & TCr & Total Cr \\
\hline RSC & $\begin{array}{c}\text { Residual sodium } \\
\text { Carbonate ratio }\end{array}$ & TDS & Total dissolved solids & TCC & $\begin{array}{c}\text { Total concentration } \\
\text { of cation }\end{array}$ \\
\hline MAR & $\begin{array}{c}\text { Magnesium } \\
\text { adsorption ratio }\end{array}$ & EC & $\begin{array}{c}\text { Electrical conductance } \\
\text { Kelley's ratio }\end{array}$ & Eh/ORP & $\begin{array}{c}\text { Oxidation reduction } \\
\text { potential }\end{array}$ \\
\hline
\end{tabular}

the surface water, groundwater, and its environment exists. The calculation formula is as follows:

$$
C A I-1=\frac{[C l-(N a+K)] / C l}{C l}
$$

...where all ionic concentrations are expressed in terms of $\mathrm{mg} / \mathrm{L}$.

The categories are based on the Environmental Quality Standards for surface wate (GB3838-2002). The list of abbreviations in the paper is found in Table 2.

For the data appearing in Figs 9 and 11, the corresponding indicators are shown in Tables 5 and 6 in the supplementary materials.

\section{Software}

Major ion compositions were used to identify the water types with the help of the AquaChem software (version 4.0). SPSS (version 17.0) was used to calculate the statistical principle components among anions and cations of the surface water and groundwater samples. MAPGIS (version 6.7) was used for the mapping of the sample locations, and to show the spatial distribution.

\section{Results and Discussion}

The groundwater chemistry depends on different hydro-geochemical processes that the groundwater undergoes over space and time. The variation of water quality is due to the combined effects of natural and anthropogenic factors, the natural factors include such things as the geological structure where groundwater is stored, the composition of the precipitation, the interaction between the groundwater and aquifer minerals such as in oxidation/reduction, cation exchange, precipitation/dissolution of minerals, and mixing of waters. The anthropogenic factors include leaching of fertilizers, manure, and biological and micro-biological factors. The interaction between the surface water and groundwater can also affect water chemistry.
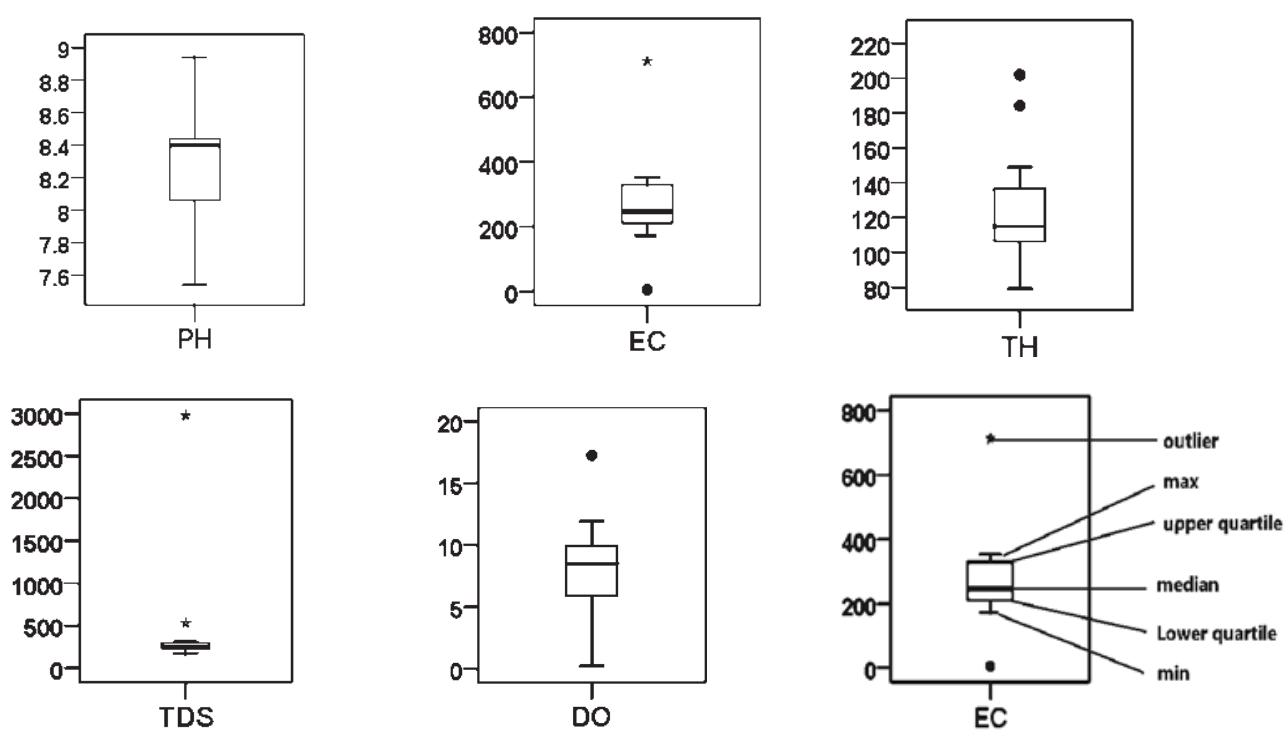

Fig. 2. Box and whisker plot of the $\mathrm{pH}, \mathrm{EC}$ (us/cm), DO (mg/L), TH (mg/L), and TDS (mg/L) data for the surface water samples in the study area 

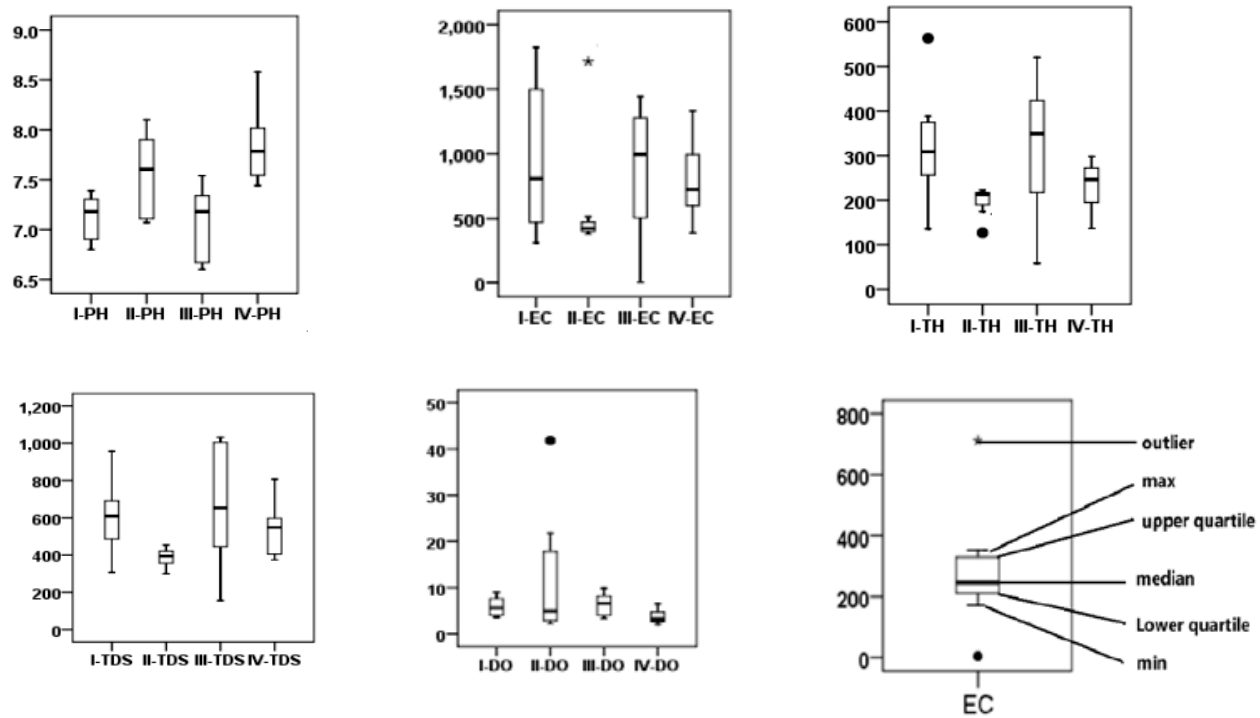

Fig. 3. Box and whisker plots of the $\mathrm{pH}, \mathrm{EC}$ (us/cm), DO (mg/L), TH $(\mathrm{mg} / \mathrm{L})$, and TDS $(\mathrm{mg} / \mathrm{L})$ data for the groundwater samples in the study area.

\section{Physicochemical Characteristics and Water Type}

The $\mathrm{pH}$ value of the surface water in the study area is from 7.54-8.94, the average value is 8.24 (Fig. 2, Table 7), and the $\mathrm{pH}$ distribution range of shallow groundwater I-II-III-IV is 6.8-7.39, with an average of $7.12,7.07-8.10$ with an average of $7.55,6.55-8.59$ with an average of 7.65, and 7.26-9.07 with an average of 7.97 (Fig. 3, Table 8), indicating that the overall environment of the area is alkaline.

The EC range of the surface water is $4.23-712 \mathrm{us} / \mathrm{cm}$ with an average of $282.65 \mathrm{us} / \mathrm{cm}$ (Fig. 2, Table 7), and the EC range of the subarea groundwater is $309-1826 \mathrm{us} / \mathrm{cm}, 377-1715 \mathrm{us} / \mathrm{cm}, 3.51-2360 \mathrm{us} / \mathrm{cm}$, and 3.36-2194 us/cm (Fig. 3, Table 8), respectively. With a mean value of 529.62-747.06 us/cm, the average EC of the surface water is lower than the average EC value of each subarea of groundwater. Surface water directly receives the influence of atmospheric precipitation, while the groundwater is recharged by atmospheric precipitation, and is also affected by the regional runoff path. The EC of the surface water and groundwater is basically lower than the WHO permissible limits (1000 us/cm).

The DO and Eh values in the water body represent the redox state of the water environment. In general, the Eh value of groundwater is lower than that of the surface water as it is in contact with the atmosphere. The onsite measurement of Eh is difficult, in order to measure the true value of the water body. The value given is for reference only, and no specific analysis is made. The TDS from $92 \%$ of the surface water and groundwater samples is less than $1 \mathrm{~g}$ per liter, which suggests weak mineralized water. In general, the TDS in the overall water body comes from the natural environment and sewage discharge. The total hardness is the dissolved amount of calcium and magnesium ions in the water body. The value of the TDS for the surface water in the study area is $168-2979 \mathrm{mg} / \mathrm{L}$, the $\mathrm{TH}$ is from 79.26-201.94 mg/L (Fig. 2, Table 7), the total TDS distribution in groundwater is $155-2107 \mathrm{mg} / \mathrm{L}$, and the TH is 58.25-978.64 mg/L (Fig. 3, Table 8). The TDS of the surface water is greater than that of the groundwater,

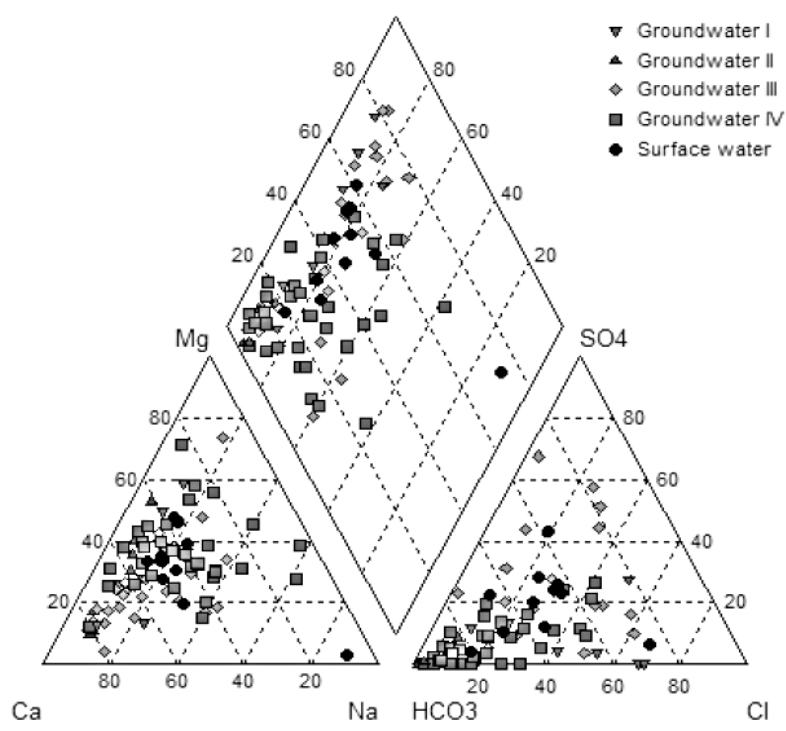

Fig. 4. Piper plot of analyzed surface water and groundwater in this region. Groundwater I controls the area between the Linjiang Bridge and Songhuajiang Village section, Groundwater II controls the area between the South Hill Section and Songhuajiang Village section, Groundwater III controls the area between the South Hill Section and Zhenjiangkou section, and Groundwater IV controls the area below Zhenjiangkou Section. The site of each section is illustrated in Fig. 1. 
whereas the TH is less than the distribution of groundwater. It is speculated that surface water is more affected by effluent discharge than groundwater.

The concentration of chloride ions in the surface water sampling point (in Fig. 1d) in the eastern part of Da'an City is as high as $801.79 \mathrm{mg} / \mathrm{L}$. The sampling point is located in the lower reaches of the second Songhua River, and the TDS index concentration is as high as $2979 \mathrm{mg} / \mathrm{L}$. According to the "Environmental Quality Standards for Surface Water" (GB3838-2002), the $\mathrm{COD}_{\mathrm{Mn}}$ and DBS indicators of the sampling point are 192.5 times and 1.5 times that of the standard value of class III, respectively, and the concentrations of the remaining indicators are the maximum values (beyond the Class III standard limit) in almost all the surface water sampling points. In particular, the high arsenic and high fluorine problems are more serious. The location of the sampling point is in the arid salinealkali area of the study area, and the water temperature at the time of sampling was $30.6^{\circ} \mathrm{C}$, which may explain the problem. The concentration of each indicator of the surface water sample is concentrated by evaporation. These results show that the water problem in the lower reaches of the Second Songhua River is more serious.

Hydrogeochemical facies are helpful to find the chemical characteristics of water with respect to cation-anion pairs. These are masses of water that have various hydrogeochemical characteristics. The chemical differences between the surface water and the groundwater were illustrated using Piper Trillinear diagrams, shown in Fig. 4.
The Piper plot of the surface water points in the study area (Fig. 4), revealing that four of the samples were $\mathrm{Ca}-\mathrm{Mg}-\mathrm{HCO}_{3}$, while of the remaining seven water points, four are $\mathrm{Mg}-\mathrm{Ca}-\mathrm{HCO}_{3}$, and three are $\mathrm{Mg}-\mathrm{Na}-\mathrm{HCO}_{3}, \mathrm{Na}-\mathrm{Mg}-\mathrm{HCO}_{3}$, and $\mathrm{Na}-\mathrm{Cl}$, respectively. The Piper plot of the regional groundwater point reveals that the 76 sampling points are dominated by $\mathrm{Ca}-\mathrm{HCO}_{3}$, $\mathrm{Ca}-\mathrm{Mg}-\mathrm{HCO}_{3}$, and $\mathrm{Ca}-\mathrm{Na}-\mathrm{HCO}_{3}$-type water, followed by $\mathrm{Ca}-\mathrm{Na}-\mathrm{Cl}, \mathrm{Ca}-\mathrm{HCO}_{3}$, and $\mathrm{Ca}-\mathrm{Mg}-\mathrm{Cl}, \mathrm{Ca}-\mathrm{Na}-\mathrm{HCO}_{3}$, and other scatter distributions.

According to the main water chemistry characteristics in the study area revealed by the Piper three-line diagram (Fig. 4), the main cations in the water samples are $\mathrm{Ca}^{2+}$ and $\mathrm{Mg}^{2+}$, and the anion is mainly $\mathrm{HCO}_{3}^{-}$, the distribution of $\mathrm{HCO}_{3}-\mathrm{Ca}$ and $\mathrm{HCO}_{3}-\mathrm{Na}$. $\mathrm{Ca}$ type water accounts for more than $60 \%$ of the total (Fig. 5).

\section{Isotopic Hydrology Analysis}

The isotopic composition measurements for the surface water and the groundwater were plotted in Fig. 6. The $\delta^{18} \mathrm{O}$ and $\delta \mathrm{D}$ isotopic composition measurements of the surface water (Table 9) ranged from $-11.80 \%$ to $-5.44 \%$ with a mean of $-9.76 \%$, and from $-81.98 \%$ to $-51.63 \%$ with a mean of $-72.58 \%$, respectively. The $\delta^{18} \mathrm{O}$ and $\delta \mathrm{D}$ isotopic composition measurements of the groundwater (Table 9) ranged from $-10.50 \%$ to $-9.30 \%$ with a mean of $-9.94 \%$, and from $-77.50 \%$ to $-69.30 \%$ with a mean of $-73.16 \%$, respectively.

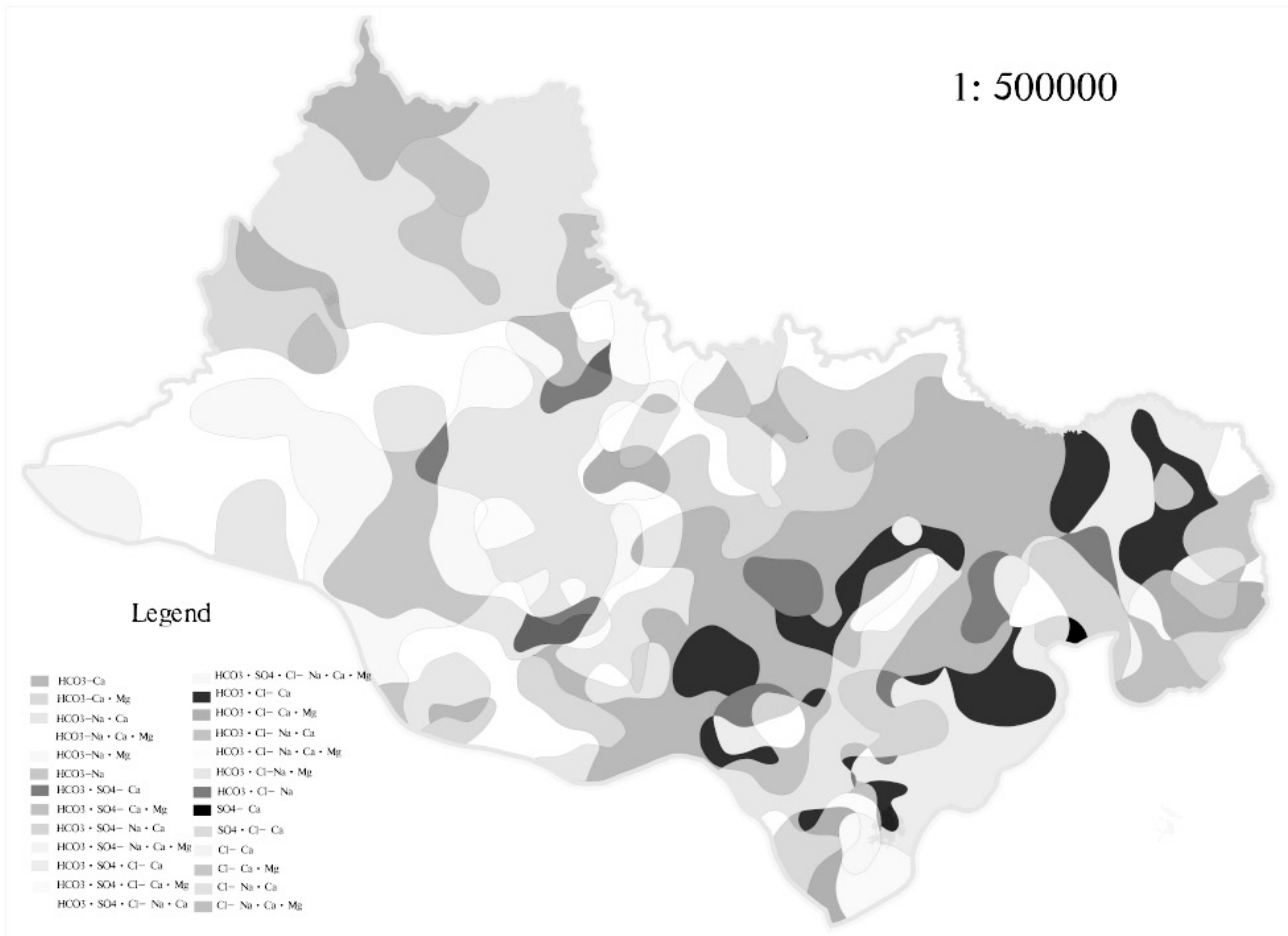

Fig. 5. Each code on the map corresponds to the phreatic water environment unit and the corresponding lithology distribution, and the map of the study area showing hydrogeochemical types. 


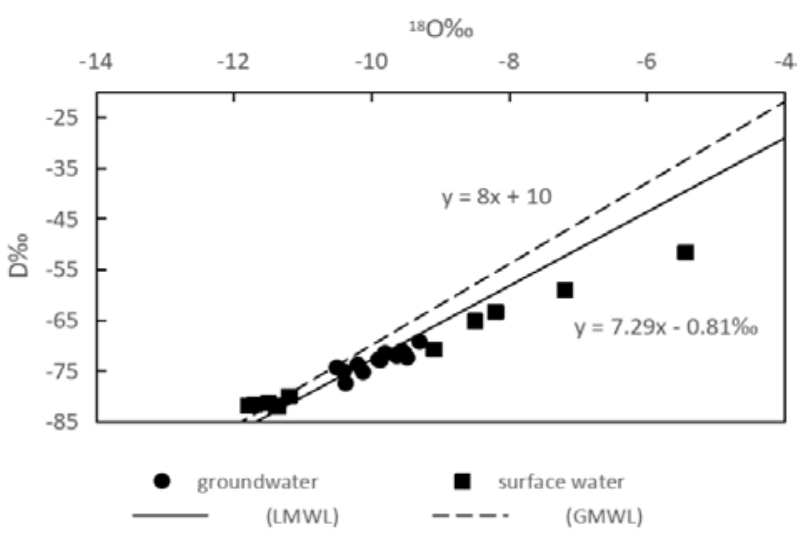

Fig. 6. Line of regression between oxygen-18 and deuterium for the LMWL, GWML, surface water, and groundwater in the study area. The data of LMWL was from the paper written by WEI Wen, CHEN Zongyu, in 2017 [28].

From the plot (Fig. 6), the isotopic content of the groundwater in the study area is distributed on the atmospheric precipitation line, indicating that the groundwater is recharged by atmospheric precipitation, and the isotopic content of the surface water is distributed between the local atmospheric precipitation line and the global atmospheric precipitation line. Compared with the groundwater point deviation, the isotope content of some surface waters is enriched due to evaporation, but most of them are depleted because of the recharge of groundwater. From the distribution of surface water and groundwater isotope content, the scope of the surface water is larger than that of groundwater, and the isotope content of the groundwater is more concentrated and stable. This shows that the recharge source of the groundwater is relatively stable, which is atmospheric precipitation infiltration and surface water. The exposed surface also has stronger evaporation than the groundwater. As a result, the isotopic content of surface water is less concentrated and less stable than that of groundwater [27-28].

In this study, however, stable isotopes were adapted to aid in the identification and the origin of dissolved ions in the rivers and hand-dug wells of the study area. The calculation results of the multisource mass balance model showed that the contribution of the groundwater to surface water recharge is $44.78 \%$ and the contribution of precipitation to groundwater recharge is $43.87 \%$.

In Fig. 7 we observed that the nitrate concentration for the surface water and groundwater in areas II and III of the groundwater were elevated, indicating anthropogenic sources in the middle watershed of the region.

Additionally, from the plot it was observed that the recharge zone and runoff zone of the groundwater are located downstream of surface water, and the discharge zone is located upstream of surface water. The oxygen-18 isotope distribution in the downstream area is more dispersed, and in the upstream area is more

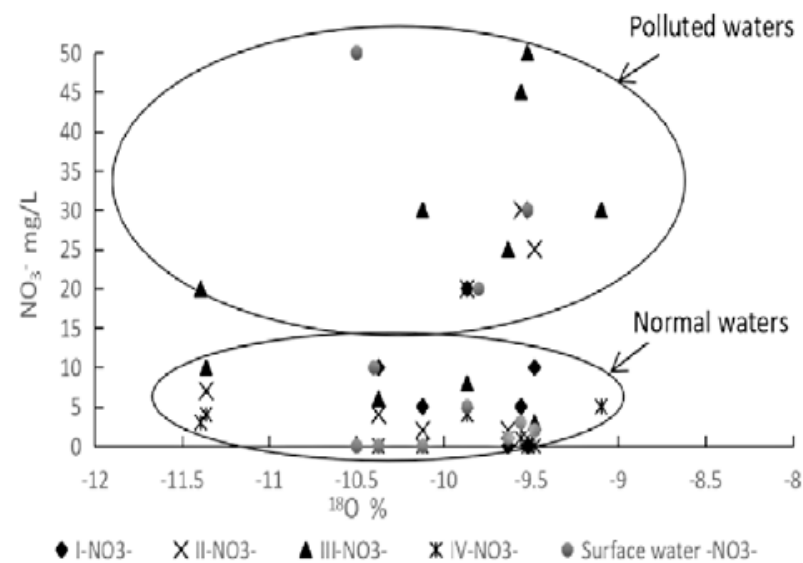

Fig. 7. Scatter plot of oxygen-18 and nitrate concentration of the surface water and groundwater in the region. Groundwater I controls the area between the Linjiang Bridge and Songhuajiang Village section, Groundwater II controls the area between the South Hill Section and Songhuajiang Village section, Groundwater III controls the area between the South Hill Section and Zhenjiangkou section, and Groundwater IV controls the area below Zhenjiangkou section. The site of each section is illustrated in Fig. 1.

concentrated, suggesting that the water supply sources in the groundwater recharge and runoff areas are more complex and diverse, while the water source in the excretory area is simpler and more stable.

\section{CA and PCA Analysis}

Factor analysis statistical methods can help identify regional water quality problems caused by natural and human activities [28-30]. This study used two methods in combination. The Varimax rotated factor loading for the surface water is presented in Fig. 8 and Table 10. Extract five principal components with eigenvalues greater than 1. For Factor 1, the information includes $43.836 \%$ of all variables, including $\mathrm{Ca}^{2+}, \mathrm{K}, \mathrm{Na}, \mathrm{Cl}$, $\mathrm{SO}_{4}^{2-}, \mathrm{HCO}_{3}^{-}, \mathrm{F}, \mathrm{SiO}_{2}, \mathrm{Cu}, \mathrm{As}$, and I, and a total of 12 parameters, between $\mathrm{K}, \mathrm{Na}, \mathrm{HCO}_{3}^{-}$, and $\mathrm{SiO}_{2}$. High loading implies silicate weathering, high scores for $\mathrm{Ca}^{2+}, \mathrm{K}, \mathrm{Na}, \mathrm{SO}_{4}{ }^{2-}$, and $\mathrm{HCO}_{3}^{-}$means carbonate mineral dissolution, and high loading between $\mathrm{Ca}^{2+}, \mathrm{K}$, and $\mathrm{Na}$ implies an ion exchange process. $\mathrm{F}, \mathrm{Cu}, \mathrm{As}$, and $\mathrm{I}$ also belong to Factor 1, which contains indicators that do not reflect the impact of human activities, suggesting that they have a common source, the largest possible geochemical role, and symbiotic or simultaneous dissolution with silicate minerals.

Factor 2 controls $27.278 \%$ of the water chemistry parameters, including $\mathrm{NO}_{2}^{-}, \mathrm{SiO}_{2}, \mathrm{Mn}, \mathrm{Zn}, \mathrm{Pb}, \mathrm{Cr}$ tot, $\mathrm{Al}$, and Fe. Excluding the loading of $\mathrm{SiO}_{2}$, which is negative, all other values are positive, suggesting that $\mathrm{Mn}, \mathrm{Zn}, \mathrm{Pb}, \mathrm{Cr}$ tot, $\mathrm{Al}$ and $\mathrm{Fe}$ do not originate from the dissolution of silicate minerals. The high $\mathrm{NO}_{2}^{-}$content indicates that the water body has been contaminated. The surface water points in the study area are located 

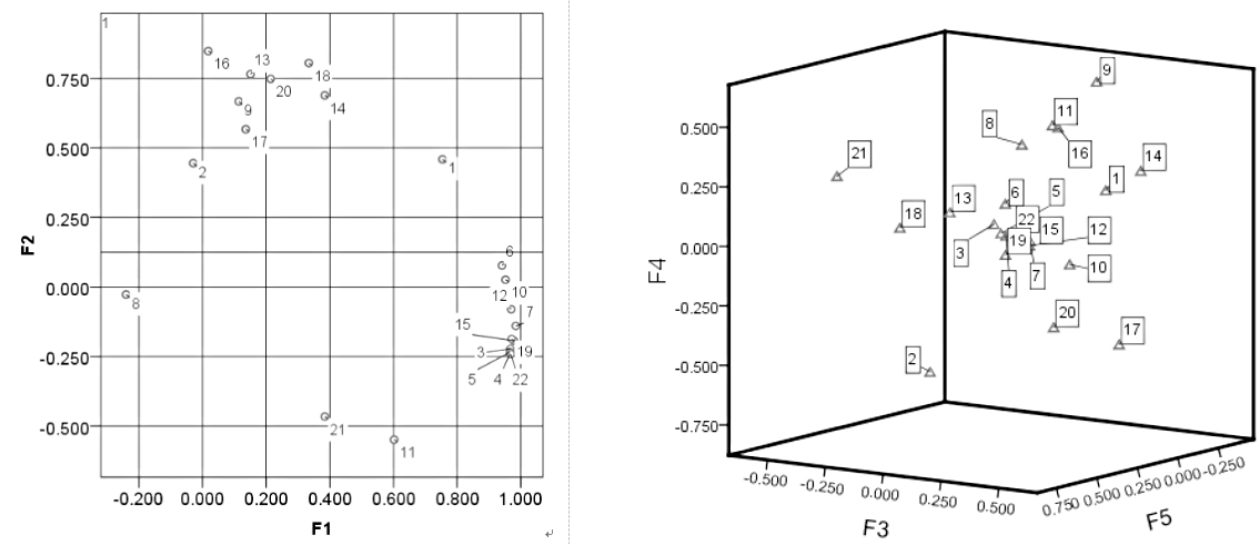

Fig. 8. PCA plot of the surface water (Rectangular, 2D, and 3D diagrams of factors; the numbers are shown in Table 5).

in the agricultural irrigation area, where discharge and withdrawal of irrigation water occurs. The surface water in the area has been affected by the application of agricultural fertilizers and pesticides, and it has begun to show signs of being contaminated. Factor 3 has a variance of about $9.091 \%$, including $\mathrm{Cr}$ tot; Factor 4 has a variance of about $7.470 \%$, including $\mathrm{Mg}, \mathrm{Cr}$ tot, $\mathrm{NO}_{3}^{-}$, and $\mathrm{NO}_{2}^{-}$; and Factor 5 has a variance of about $7.470 \%$, including $\mathrm{NO}_{3}^{-}$and DBS. Factors 3, 4, and 5 together explain the area surface water contamination by agrochemical fertilizers, and also the effect of domestic sewage.

The Varimax rotated factor loading for the groundwater has been presented in Fig. 9 and Table 11. The extraction of eight principal components with a feature root value greater than 1 . Factor 1 contains $18.948 \%$ of all variables, including $\mathrm{Na}, \mathrm{HCO}_{3}^{-}, \mathrm{F}$, and $\mathrm{I}$, suggesting the weathering and dissolution of silicate minerals in the regional groundwater. At the same time, the two indicators $\mathrm{F}$ and I have a common source, suggesting the symbiosis of minerals. Factor 2 controls $14.662 \%$ of the water chemistry parameters, including $\mathrm{K}, \mathrm{Mn}$, and $\mathrm{Fe}$. However, there was no evidence to show that they originated from human activities. It is speculated that $\mathrm{Mn}$ and $\mathrm{Fe}$ are the influence of the region's primary geological environment. According to previous studies [31], regional water quality is affected by these two indicators. Overall, Factor 3, with a variance of about $0.919 \%$, includes $\mathrm{Mg}, \mathrm{Na}$, and $\mathrm{SO}_{4}{ }^{2+}$, suggesting that $\mathrm{Mg}$ is from the dissolution of carbonate minerals, as well as ion exchange between $\mathrm{Mg}$ and $\mathrm{Na}$. Factor 4, with a variance of about $8.013 \%$, includes $\mathrm{Pb}, \mathrm{TCr}$, and $\mathrm{Al}$. Factor 5, with a variance of about $6.674 \%$, includes $\mathrm{Ca}, \mathrm{Cl}$, and $\mathrm{NO}_{3}^{-}$. Factor 6, with a variance of about $5.530 \%$, includes $\mathrm{NO}_{2}^{-}$and $\mathrm{COD}_{\mathrm{Mn}}$. Factors 5 and 6 imply that the groundwater is also contaminated by agrochemical fertilizers, and its scores are relatively higher than that of the surface water, suggesting that the irrigation leakage of agricultural irrigation water is responsible for the pollution of the surface irrigation water. Factor 7, with a variance of about $4.897 \%$, includes $\mathrm{Cu}$ and DBS and is relatively serious, suggesting that the groundwater is also affected by domestic sewage. We can also speculate that the $\mathrm{Cu}$ may be derived from human activities, in addition to natural factors.

\section{Hydrogeology Process of the Surface Water and Groundwater}

The surface water Gibbs plot [32-34] (Fig. 10a, b) for the study area indicated that the ion composition
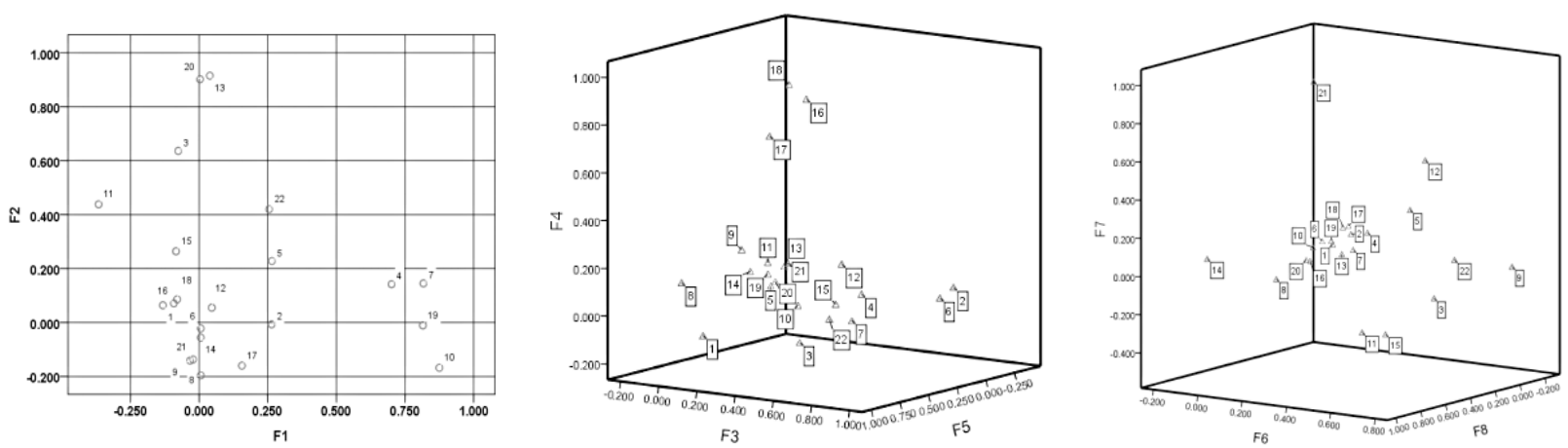

Fig. 9. PCA plot of the groundwater (Rectangular, 2D, and 3D diagrams of factors; the numbers are shown in Table 6). 

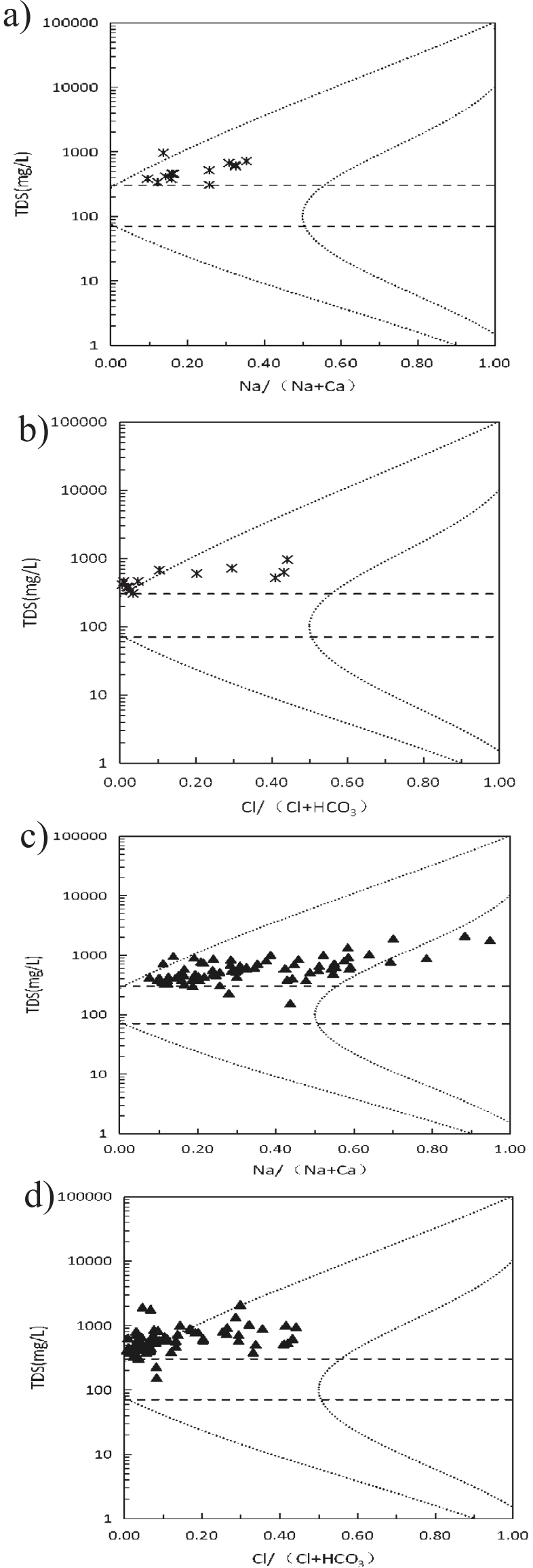

Fig. 10. Gibbs plot of the surface water $(a, b)$ and groundwater (c, d) in the study area, showing similarities of the water sample distribution between the surface water and groundwater. for the surface water was controlled by evaporation crystallization. The groundwater Gibbs plot (Fig. 10 c, d) also revealed evaporation crystallization as the dominant process controlling the major ion composition for $96 \%$ of the groundwater samples. Only $4 \%$ were controlled by rock dominance weathering. This conclusion confirms that there is a relationship between the surface water and groundwater.

The calculated negative CAI-1 value indicates that the $\mathrm{Cl}$ content in the water is lower than the $\mathrm{Na}$ content $(\mathrm{Na}+\mathrm{K})$, and the partial $\mathrm{Na}$ content in the water is ion exchanged with $\mathrm{Ca} . \mathrm{Mg}$ in the rock along the water flow, on the contrary, belongs to a type of anion-cation exchange reaction.

In this study, for the 11 surface water samples, the values of CAI-1 calculated at points $1,3,5,6$, and 8 were negative, and the rest were positive. The CAI-1 calculation results of the groundwater show that $37.5 \%$ of the groundwater points in the I zone are negative, $100 \%$ of the groundwater points in the II zone are negative, $76.9 \%$ of the groundwater points in the III zone are negative, and $94.1 \%$ of the groundwater points in the IV zone are negative. The negative CAI-1 values show that the exchange of $\mathrm{Na}+\mathrm{K}$ in the water with the $\mathrm{Ca}+\mathrm{Mg}$ in the rock of the water flow environment from the upper Songhuajiang village section to the downstream Zhenjiangkou section is gradually enhanced. The cation exchange effect of the tributary of the Yinma River and the downstream is particularly strong, and the cation-anion exchange type of reaction in the upper Songhuajiang village area is relatively strong.

In summary, the water chemical composition of the Second Songhua River Basin is mainly derived from evaporation crystallization, rock weathering, and ion exchange.

\section{Water Quality for Irrigation}

The research area has carried out a river-lake connectivity project since 2015, aiming to conduct regional surface water connectivity projects to improve the state of environment. The Songyuan Irrigation District, which is one of the more important subprojects of the project, and the project mainly uses the Second Songhua River and the surface lakes in the area for irrigation of crops. Up until now, there was also a large proportion of groundwater irrigation crops being grown to help the growth of the agricultural area in the region. Determining whether the surface and groundwater in the study area are suitable for irrigation is a major issue concerning the national economy and the people's livelihoods. However, irrigation can cause deterioration of soil permeability, soil compaction, and salinization.

The concentration of sodium is an important indicator for evaluating the suitability of water for irrigation, because sodium in the water reacts with calcium and magnesium in the soil, causing clogging of soil particles - reducing the permeability of the soil, and changing the structure of the soil. The 
Table 3. Rating of water samples based on the EC and percentage of sodium, by Wilcox.

\begin{tabular}{|c|c|c|c|c|}
\hline Category & Surface water $\mathrm{n}=11$ & $\%$ & Groundwater $\mathrm{n}=76$ & $\%$ \\
\hline Excellent to good & 11 & $100 \%$ & 30 & $39 \%$ \\
\hline Good to permissible & 0 & $0 \%$ & 0 & $50 \%$ \\
\hline Permissible to doubtful & 0 & $0 \%$ & 8 & $0 \%$ \\
\hline Doubtful to unsuitable & 0 & $0 \%$ & 0 & $0 \%$ \\
\hline Unsuitable & 0 & $0 \%$ & & $11 \%$ \\
\hline
\end{tabular}

reduced ability of the soil to maintain stability makes it compact and tightly impermeable to water, which is very detrimental to crop production. In addition, sodium combines with $\mathrm{CO}_{3}{ }^{2-}$ to accelerate the formation of alkaline soils, and combines with $\mathrm{Cl}^{-}$to form saline soil, neither of which are helpful for crop growth. In order to evaluate the applicability of agricultural irrigation to water bodies in the region, calculations of sodiumrelated parameters such as SSP, SAR, RSC, MAR, and KR were performed.

Wilcox [33] planned a method for rating waters for irrigation based on the percentage of sodium and electrical conductivity. The calculated $\mathrm{Na} \%$ in the samples was plotted against electrical conductivity (Fig. 11). According to Wilcox, $100 \%$ of the surface water samples are allowed for agriculture purposes; 39\% of the groundwater samples are "excellent to good" for agriculture purposes, $50 \%$ of the groundwater samples are "good to permissible" for agriculture purposes, and $11 \%$ of the groundwater samples are "doubtful to unsuitable" for agriculture purposes (Table 3).

SAR is an estimate of the extent to which sodium ions present in the water would be absorbed in the soil. The higher the SAR value, the greater the risk of the sodium posing a hazard to plant growth (Fig. 12)
The US Salinity Laboratory's (USSL) diagram proposed by Richards (1954) is used to investigate the sampled water, which shows that $60 \%$ of the groundwater samples are in the high salinity hazard category (C3), and $91 \%$ of the surface water samples are in the low sodium hazard category and the medium salinity hazard category.

According to Table 4, in terms of the MAR and KR indicators of surface water and groundwater in the study area, more than $90 \%$ of the surface water points and more than $86 \%$ of the groundwater points are suitable as irrigation water. In terms of the RSC indicator, more than $81 \%$ of the surface water and groundwater are good for irrigation. The SSP index calculation results show that $90.91 \%$ of the surface water points are good for irrigation, and $100 \%$ of the groundwater points are excellent for irrigation.

The SSP and KR indicators were all evaluated from the perspective of the proportion of $\mathrm{Na}^{+}$in the water of the study area. The MAR indicators were analyzed from the perspective of the proportion of $\mathrm{Mg}^{2+}$ in the water. The ratio of $\mathrm{Na}^{+}$content in the water was accounted for by the greater possibility of exchanging $\mathrm{Ca}^{2+}$ and $\mathrm{Mg}^{2+}$ in the soil. If such a water body is used as irrigation, the soil is more likely to form saline soil. The SAR

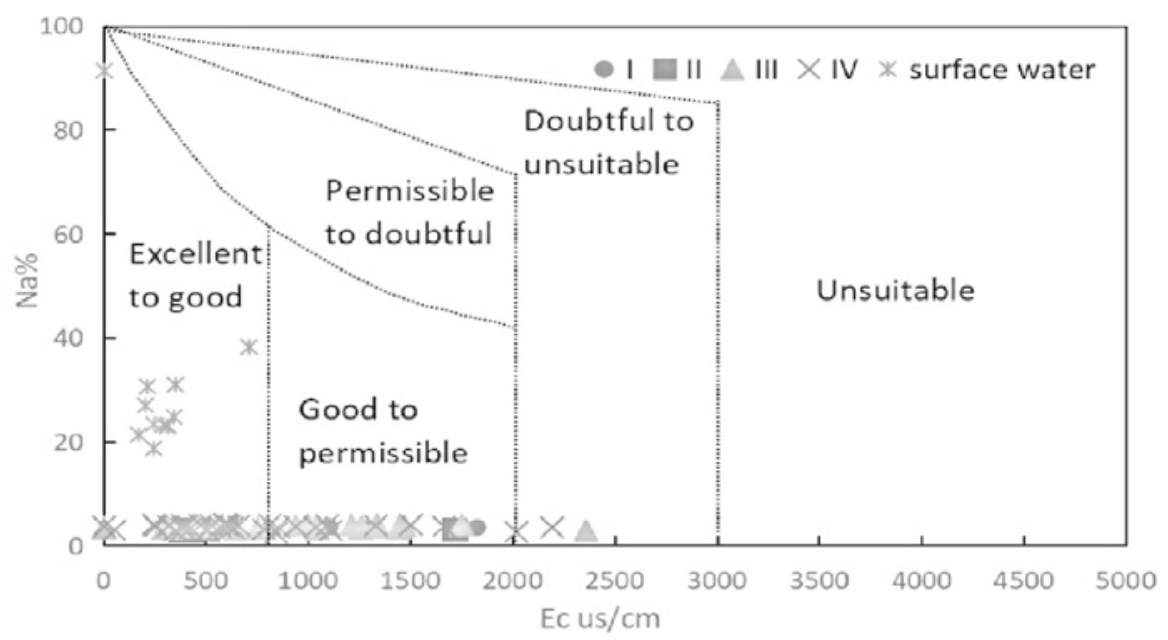

Fig. 11. Rating of surface water and groundwater samples on the basis of EC and percentage of sodium. According to EC and Na, percentage suitability can be divided into five regions, and the water samples falling in each region represent their different evaluation levels for suitability as irrigation water. 


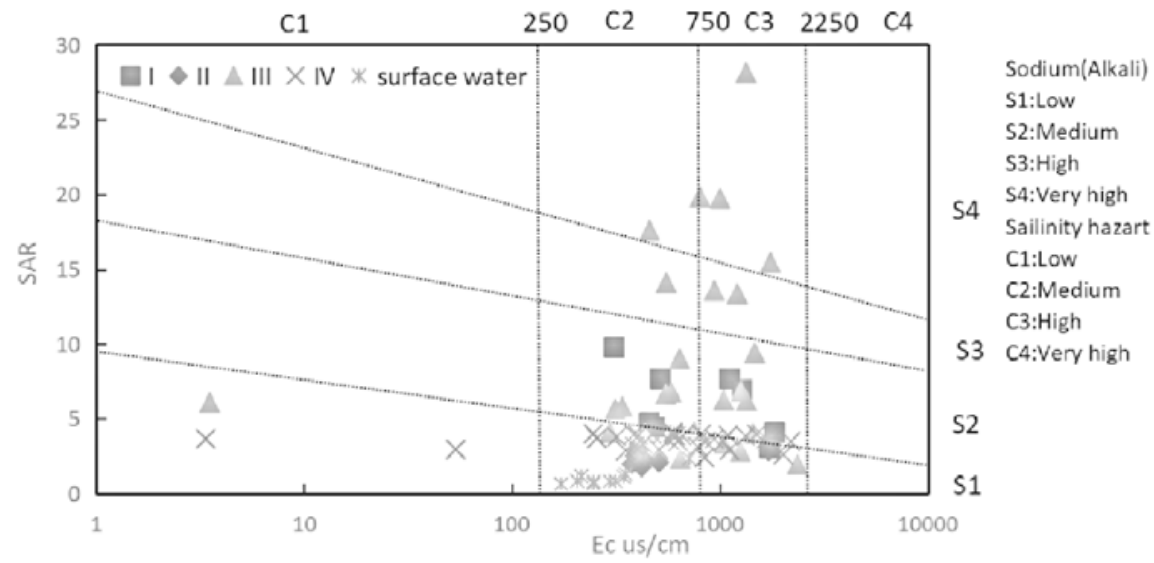

Fig. 12. US Salinity Laboratory (USSL) diagram representing the salinity and sodium hazard. According to EC and SAR, it is divided into 16 regions, and the water samples falling in each region represent different evaluation levels of the plant growth hazard for irrigation water.

Table 4. Geochemical classification of surface water and groundwater in the region. Irrigation water quality evaluation results for the surface water and groundwater using the SSP, RSC, MAR, and KR indices.

\begin{tabular}{|c|c|c|c|c|c|c|c|}
\hline Category & Grade & $\mathrm{n}=11 / 76$ & $\%$ & Category & Grade & $\mathrm{n}=11 / 76$ & $\%$ \\
\hline & SSP & & & & $\mathrm{RSC}$ & & \\
\hline Excellent & $0-20$ & 0 & 0.00 & Good & $<1.25$ & 9 & 81.82 \\
\hline Good & $20-40$ & 10 & 90.91 & Medium & $1.25-2.5$ & 1 & 9.09 \\
\hline Permissible & $40-60$ & 0 & 0.00 & $\mathrm{Bad}$ & $>2.5$ & 1 & 9.09 \\
\hline Doubtful & $60-80$ & 0 & 0.00 & & MAR & & \\
\hline Unsuitable & $>80$ & 1 & 9.09 & Suitable & $<50$ & 11 & 100.00 \\
\hline 8 & $\mathrm{C}(\mathrm{us} / \mathrm{cm})$ & & & Unsuitable & $>50$ & 0 & 0.00 \\
\hline Excellent & $<250$ & 6 & 54.55 & & $\mathrm{KR}$ & & \\
\hline Good & $250-750$ & 5 & 45.45 & Suitable & $<1$ & 10 & 90.91 \\
\hline Permissible & $750-2250$ & 0 & 0.00 & Unsuitable & $>1$ & 1 & 9.09 \\
\hline Doubtful & $2250-5000$ & 0 & 0.00 & & & & \\
\hline Unsuitable & $>5000$ & 0 & 0.00 & & & & \\
\hline & SSP & & & & $\mathrm{RSC}$ & & \\
\hline Excellent & $0-20$ & 76 & 100.00 & Good & $<1.25$ & 64 & 84.21 \\
\hline Good & $20-40$ & 0 & 0.00 & Medium & $1.25-2.5$ & 8 & 10.53 \\
\hline Permissible & $40-60$ & 0 & 0.00 & $\mathrm{Bad}$ & $>2.5$ & 4 & 5.26 \\
\hline Doubtful & $60-80$ & 0 & 0.00 & & MAR & & \\
\hline Unsuitable & $>80$ & 0 & 0.00 & Suitable & $<50$ & 66 & 86.84 \\
\hline \begin{tabular}{l}
$\sum_{2}^{2}$ \\
\multirow{2}{*}{}
\end{tabular} & $\mathrm{EC}(\mathrm{us} / \mathrm{cn}$ & & & Unsuitable & $>50$ & 10 & 13.16 \\
\hline Excellent & $<250$ & 4 & 5.26 & & $\mathrm{KR}$ & & \\
\hline Good & $250-750$ & 39 & 51.32 & Suitable & $<1$ & 72 & 94.74 \\
\hline Permissible & $750-2250$ & 32 & 42.11 & Unsuitable & $>1$ & 4 & 5.26 \\
\hline Doubtful & $2250-5000$ & 1 & 1.32 & & & & \\
\hline Unsuitable & $>5000$ & 0 & 0.00 & & & & \\
\hline
\end{tabular}


Table 5. Part of chemical compositions of surface water samples.

\begin{tabular}{|c|c|c|c|c|c|c|c|c|c|}
\hline ID & Sample ID & Water temper $\left({ }^{\circ} \mathrm{C}\right)$ & PH & Turbidity/NTU & EC us/cm & Eh/mv & DO/mg/L & TH/mg/L & TDS/mg/L \\
\hline 1 & 2012101705 & 8.5 & 8.44 & 125.6 & 205.8 & 115.1 & 10.49 & 79.26 & 168 \\
\hline 2 & 2012101805 & 8.9 & 8.94 & 20.5 & 247 & 132.8 & 11.92 & 114.93 & 204 \\
\hline 3 & 2012102006 & 8.1 & 8.41 & 117.5 & 215.7 & 125.2 & 17.25 & 103.04 & 261 \\
\hline 4 & 2013080908 & 30.6 & 8.4 & 17.6 & 4.23 & -27.6 & 0.21 & 184.11 & 2979 \\
\hline 5 & 2013103004 & 7 & 8.15 & 17.2 & 345 & -19.5 & 5.3 & 149.06 & 312 \\
\hline 6 & 2013103103 & 9 & 8.24 & 46.2 & 246 & 71 & 6.15 & 109.6 & 221 \\
\hline 7 & 2014070113 & 20 & 8.44 & 195 & 314 & 82.5 & 9.26 & 124.27 & 242 \\
\hline 8 & 2014070601 & 18.8 & 7.97 & 40.5 & 172.4 & 152 & 8.29 & 89.32 & 227 \\
\hline 9 & 2014071301 & 24.4 & 7.57 & 16.2 & 352 & 86.1 & 8.5 & 120.39 & 282 \\
\hline 10 & 2014071305 & 25.4 & 8.59 & 10.6 & 295 & 183.3 & 9.35 & 112.62 & 230 \\
\hline 11 & 2014071704 & 17 & 7.54 & 34.5 & 712 & 97.9 & 4.44 & 201.94 & 528 \\
\hline
\end{tabular}

Table 6. Part of chemical compositions of groundwater samples.

\begin{tabular}{|c|c|c|c|c|c|c|c|c|c|c|}
\hline Subarea & ID & Sample ID & $\begin{array}{c}\text { Water temper } \\
\left({ }^{\circ} \mathrm{C}\right)\end{array}$ & $\mathrm{PH}$ & $\begin{array}{l}\text { Turbidity/ } \\
\text { NTU }\end{array}$ & $\mathrm{EC}$ us/cm & $\mathrm{Eh} / \mathrm{mv}$ & $\mathrm{DO} / \mathrm{mg} / \mathrm{L}$ & $\mathrm{TH} / \mathrm{mg} / \mathrm{L}$ & $\mathrm{TDS} / \mathrm{mg} / \mathrm{L}$ \\
\hline I & 1 & 2014070401 & 11.8 & 6.8 & 2.3 & 1826 & 90.5 & 9.02 & 135.92 & 306 \\
\hline I & 2 & 2014070402 & 11.2 & 7.39 & 2 & 1728 & 204.5 & 7.75 & 233.01 & 457 \\
\hline I & 3 & 2014070406 & 8.5 & 7 & 0.4 & 1105 & 190 & 4.08 & 361.16 & 666 \\
\hline I & 4 & 2014070503 & 12.6 & 7.22 & 1.5 & 1268 & 34 & 7.42 & 388.35 & 716 \\
\hline I & 5 & 2014070511 & 10.9 & 6.81 & 2.7 & 515 & 165.6 & 6.77 & 279.61 & 593 \\
\hline I & 6 & 2014070602 & 11.4 & 7.39 & 1.9 & 457 & 96.8 & 3.6 & 306.8 & 515 \\
\hline I & 7 & 2014070608 & 11 & 7.16 & 2.6 & 309 & -36.5 & 3.99 & 310.68 & 625 \\
\hline I & 8 & 2014070611 & 10.8 & 7.2 & 2.2 & 481 & 130.6 & 4.56 & 563.11 & 957 \\
\hline II & 9 & 2012091508 & 8 & 7.07 & 1.9 & 1715 & 162.3 & 2.99 & 222.38 & 454 \\
\hline II & 10 & 2012091509 & 8.3 & 7.58 & 13.1 & 432 & 13.8 & 4.6 & 218.96 & 412 \\
\hline II & 11 & 2012091510 & 8 & 7.63 & 8.5 & 420 & 121.6 & 2.79 & 205.27 & 379 \\
\hline II & 12 & 2012091511 & 6.9 & 8.1 & 3.1 & 426 & 11.6 & 2.15 & 212.11 & 379 \\
\hline II & 13 & 2012091610 & 7.5 & 7.12 & 10.3 & 509 & 185.1 & 21.7 & 174.48 & 334 \\
\hline II & 14 & 2012091612 & 8.3 & 7.1 & 7.8 & 377 & 159.2 & 13.98 & 215.53 & 410 \\
\hline II & 15 & 2012101704 & 8.2 & 8.07 & 7.6 & 404 & 127.5 & 5.35 & 126.82 & 299 \\
\hline II & 16 & 2012101707 & 8.3 & 7.73 & 5 & 392 & 151.2 & 41.85 & 214.01 & 429 \\
\hline III & 17 & 2014070108 & 8.5 & 6.6 & 0.2 & 1337 & 100.5 & 3.3 & 388.35 & 1032 \\
\hline III & 18 & 2014070201 & 11.6 & 6.68 & 3.1 & 459 & 172.9 & 5.94 & 520.39 & 1004 \\
\hline III & 19 & 2014070204 & 8.7 & 7.12 & 2.7 & 3.51 & 1116 & 8.54 & 419.42 & 775 \\
\hline III & 20 & 2014070206 & 9 & 7.44 & 0.5 & 549 & -35 & 4.01 & 310.68 & 531 \\
\hline III & 21 & 2014070207 & 8.5 & 6.66 & 5.4 & 1212 & 185.3 & 7.73 & 221.36 & 509 \\
\hline III & 22 & 2014070306 & 10.1 & 7.24 & 3 & 940 & -21.3 & 3.98 & 427.18 & 1004 \\
\hline III & 23 & 2014070312 & 9.5 & 7.54 & 1.8 & 1443 & 614.5 & 9.88 & 213.59 & 379 \\
\hline III & 24 & 2014071105 & 11.3 & 7.24 & 2.1 & 1043 & 161.2 & 7.17 & 58.25 & 155 \\
\hline III & 25 & 2014071106 & 8.5 & 6.9 & 10.8 & 1471 & 250.3 & 6.82 & 194.17 & 386 \\
\hline
\end{tabular}


Table 6. Continued.

\begin{tabular}{|c|c|c|c|c|c|c|c|c|c|c|}
\hline III & 26 & 2014071107 & 12.1 & 7.8 & 1.9 & 1000 & 84 & 8.88 & 174.76 & 636 \\
\hline III & 27 & 2014071109 & 20 & 8.44 & 195 & 314 & 82.5 & 9.26 & 291.26 & 562 \\
\hline III & 28 & 2014071205 & 8.6 & 6.94 & 2.8 & 339 & 183.3 & 6.75 & 539.8 & 895 \\
\hline III & 29 & 2014071207 & 8.5 & 6.55 & 1.2 & 644 & 213 & 7.58 & 182.52 & 378 \\
\hline III & 30 & 2014071211 & 11.6 & 7.61 & 2.1 & 584 & 68 & 6.08 & 240.78 & 540 \\
\hline III & 31 & 2014071212 & 8.5 & 7.22 & 1.2 & 1048 & 208 & 8.34 & 256.31 & 474 \\
\hline III & 32 & 2014071214 & 8.5 & 6.78 & 4.5 & 1256 & 132.2 & 5.64 & 155.34 & 320 \\
\hline III & 33 & 2014071307 & 10.1 & 7.89 & 2.4 & 753 & 159.2 & 10.89 & 322.33 & 582 \\
\hline III & 34 & 2014071504 & 13.6 & 7.82 & 3.2 & 1342 & 134.4 & 6.7 & 326.21 & 682 \\
\hline III & 35 & 2014071509 & 12.1 & 7.45 & 1.7 & 2360 & 181.1 & 10.26 & 186.41 & 727 \\
\hline III & 36 & 2014071510 & 11.3 & 7.22 & 2.6 & 1752 & 219.3 & 8.29 & 143.69 & 483 \\
\hline III & 37 & 2014071604 & 25.4 & 8.59 & 10.6 & 295 & 183.3 & 9.35 & 225.24 & 441 \\
\hline III & 38 & 2014071611 & 10.9 & 7.82 & 2.1 & 640 & 158 & 4.06 & 388.35 & 835 \\
\hline III & 39 & 2014071612 & 9.8 & 7.9 & 2.1 & 435 & 206 & 9.6 & 100.97 & 227 \\
\hline III & 40 & 2014071613 & 10.5 & 7.7 & 1.7 & 1262 & 172.6 & 10.34 & 407.77 & 741 \\
\hline III & 41 & 2014071616 & 8.5 & 6.78 & 1.7 & 803 & -62.2 & 4.37 & 978.64 & 1892 \\
\hline III & 42 & 2014071618 & 10.5 & 7.76 & 2.2 & 552 & 163.1 & 9.36 & 365.05 & 844 \\
\hline IV & 43 & 2012091507 & 11.9 & 7.44 & 93.7 & 784 & -111 & 2.83 & 201.85 & 380 \\
\hline IV & 44 & 2012091901 & 8.2 & 7.79 & 9.8 & 386 & -152.8 & 2.1 & 253.23 & 807 \\
\hline IV & 45 & 2012091907 & 8.3 & 7.56 & 11.8 & 940 & 149.4 & 4.01 & 297.71 & 610 \\
\hline IV & 46 & 2012092001 & 9.7 & 7.53 & 18.5 & 1038 & -92 & 2.98 & 188.21 & 430 \\
\hline IV & 47 & 2012092003 & 10.1 & 7.84 & 9.9 & 570 & -141.1 & 2.55 & 239.54 & 550 \\
\hline IV & 48 & 2012092401 & 6.1 & 8.58 & 8.5 & 629 & 161.2 & 5.49 & 287.38 & 545 \\
\hline IV & 49 & 2012092406 & 10.5 & 7.78 & 43 & 1331 & 68 & 6.47 & 136.85 & 374 \\
\hline IV & 50 & 2012092502 & 9.4 & 8.19 & 11.8 & 660 & -72.9 & 3.43 & 256.59 & 585 \\
\hline IV & 51 & 2012092508 & 7.6 & 8.79 & 7 & 256 & 177.5 & 11.09 & 390.01 & 808 \\
\hline IV & 52 & 2012092602 & 7.9 & 7.52 & 8.8 & 473 & 4.2 & 10.56 & 229.22 & 720 \\
\hline IV & 53 & 2012092606 & 9.5 & 7.8 & 27.9 & 246 & -29.6 & 4.25 & 225.79 & 775 \\
\hline IV & 54 & 2012101009 & 8.6 & 8.52 & 1.9 & 597 & 2 & 6.32 & 297.24 & 890 \\
\hline IV & 55 & 2012101115 & 9 & 9.07 & 10.8 & 404 & 166.1 & 10.69 & 202.12 & 549 \\
\hline IV & 56 & 2012101204 & 8 & 8.22 & 14.5 & 596 & 179.2 & 6.3 & 344.8 & 1785 \\
\hline IV & 57 & 2012102004 & 8 & 8.57 & 3.2 & 353 & 184.2 & 8.59 & 174.38 & 327 \\
\hline IV & 58 & 2012102009 & 6.9 & 8.26 & 3.4 & 319 & 146.8 & 12.09 & 158.53 & 404 \\
\hline IV & 59 & 2012102011 & 6.1 & 7.84 & 11.6 & 599 & 59.2 & 7.65 & 269.5 & 622 \\
\hline IV & 60 & 2012102410 & 8 & 8.67 & 8.1 & 426 & 99.5 & 11.17 & 229.87 & 432 \\
\hline IV & 61 & 2012102412 & 11.7 & 7.65 & 9.9 & 1503 & 68.9 & 3.53 & 356.69 & 920 \\
\hline IV & 62 & 2012102501 & 7.5 & 8.35 & 10.3 & 814 & 129.3 & 36.5 & 190.24 & 592 \\
\hline IV & 63 & 2012102515 & 8.7 & 7.99 & 4.2 & 2194 & 132.2 & 3.84 & 229.87 & 468 \\
\hline IV & 64 & 2012102603 & 8.8 & 8.21 & 36.5 & 1095 & 35.1 & 3.83 & 253.65 & 657 \\
\hline IV & 65 & 2012102605 & 8.1 & 7.78 & 9.7 & 53.6 & 105.3 & 3.06 & 253.65 & 453 \\
\hline
\end{tabular}


Table 6. Continued.

\begin{tabular}{|c|c|c|c|c|c|c|c|c|c|c|}
\hline IV & 66 & 2012103103 & 12 & 8.18 & 4.7 & 2019 & 116 & 3.34 & 231.03 & 413 \\
\hline IV & 67 & 2012103109 & 8 & 8 & 11.9 & 390 & -91.6 & 4.33 & 259.91 & 474 \\
\hline IV & 68 & 2012103115 & 8.6 & 7.29 & 30.2 & 1665 & 31.8 & 16.62 & 276.41 & 580 \\
\hline IV & 69 & 2012110101 & 8.1 & 7.94 & 18.3 & 854 & 25.3 & 13.19 & 466.18 & 862 \\
\hline IV & 70 & 2012110103 & 11 & 7.96 & 6.3 & 844 & 10.3 & 4.7 & 239.28 & 413 \\
\hline IV & 71 & 2012110115 & 8.2 & 7.32 & 16.3 & 1111 & 41.8 & 6.42 & 198.02 & 356 \\
\hline IV & 72 & 2013080504 & 8.5 & 7.43 & 13 & 529 & 88.5 & 30.5 & 504.18 & 1337 \\
\hline IV & 73 & 2013080511 & 8.1 & 7.26 & 21.1 & 615 & 68.8 & 11.25 & 263.05 & 587 \\
\hline IV & 74 & 2013080604 & 12.4 & 8.11 & 1.3 & 3.36 & -82.3 & 2.03 & 341.97 & 692 \\
\hline IV & 75 & 2013080610 & 8 & 7.96 & 15.3 & 509 & 85.1 & 14.15 & 263.05 & 460 \\
\hline IV & 76 & 2013080701 & 8.1 & 7.41 & 9.9 & 594 & 94.4 & 25.9 & 439.65 & 2107 \\
\hline
\end{tabular}

Table 7. Statistics of the measured parameters for collected surface water samples

\begin{tabular}{|c|c|c|c|c|c|c|}
\hline Parameters & Unit & Minimum & Maximum & Mean & Std.Deviation & Coefficient of variation $(\%)$ \\
\hline Water temper $\left({ }^{\circ} \mathrm{C}\right)$ & $\left({ }^{\circ} \mathrm{C}\right)$ & 7.00 & 30.60 & 16.15 & 8.34 & 51.63 \\
\hline $\mathrm{PH}$ & - & 7.54 & 8.94 & 8.24 & 0.42 & 5.10 \\
\hline Turbidity & NTU & 10.60 & 195.00 & 58.31 & 60.48 & 103.72 \\
\hline $\mathrm{EC}$ & $\mathrm{us} / \mathrm{cm}$ & 4.23 & 712.00 & 282.65 & 172.29 & 60.96 \\
\hline Eh & $\mathrm{mv}$ & -27.60 & 183.30 & 90.80 & 65.24 & 71.85 \\
\hline DO & $\mathrm{mg} / \mathrm{L}$ & 0.21 & 17.25 & 8.50 & 4.58 & 53.91 \\
\hline $\mathrm{TH}$ & $\mathrm{mg} / \mathrm{L}$ & 79.26 & 201.94 & 126.23 & 37.86 & 30.00 \\
\hline TDS & $\mathrm{mg} / \mathrm{L}$ & 168.00 & 2979.00 & 514.00 & 823.03 & 160.12 \\
\hline $\mathrm{Ca}^{2+}$ & $\mathrm{mg} / \mathrm{L}$ & 20.22 & 65.32 & 35.10 & 14.84 & 42.28 \\
\hline $\mathrm{Mg}^{2+}$ & $\mathrm{mg} / \mathrm{L}$ & 4.81 & 13.21 & 9.23 & 2.14 & 23.23 \\
\hline $\mathrm{K}^{+}$ & $\mathrm{mg} / \mathrm{L}$ & 1.29 & 39.83 & 6.57 & 11.11 & 169.16 \\
\hline $\mathrm{Na}^{+}$ & $\mathrm{mg} / \mathrm{L}$ & 9.66 & 865.50 & 96.08 & 255.49 & 265.91 \\
\hline $\mathrm{Cl}^{-}$ & $\mathrm{mg} / \mathrm{L}$ & 8.86 & 801.79 & 91.98 & 235.84 & 256.40 \\
\hline $\mathrm{SO}_{4}^{2-}$ & $\mathrm{mg} / \mathrm{L}$ & 4.21 & 138.37 & 41.45 & 37.09 & 89.49 \\
\hline $\mathrm{HCO}_{3}^{-}$ & $\mathrm{mg} / \mathrm{L}$ & 63.88 & 915.70 & 200.24 & 242.24 & 120.98 \\
\hline $\mathrm{NO}_{3}^{-}$ & $\mathrm{mg} / \mathrm{L}$ & 0.00 & 50.00 & 11.00 & 16.15 & 146.81 \\
\hline $\mathrm{NO}_{2}^{-}$ & $\mathrm{mg} / \mathrm{L}$ & 0.00 & 0.70 & 0.09 & 0.20 & 225.86 \\
\hline $\mathrm{F}^{-}$ & $\mathrm{mg} / \mathrm{L}$ & 0.24 & 1.66 & 0.57 & 0.41 & 70.58 \\
\hline $\mathrm{SiO}_{2}$ & $\mathrm{mg} / \mathrm{L}$ & 3.99 & 30.08 & 14.79 & 7.06 & 47.73 \\
\hline $\mathrm{COD}_{\mathrm{Mn}}$ & $\mathrm{mg} / \mathrm{L}$ & 1.94 & 29.66 & 5.27 & 8.11 & 153.83 \\
\hline $\mathrm{Cu}$ & ug/L & 0.00 & 48.40 & 9.37 & 13.51 & 144.14 \\
\hline $\mathrm{Mn}$ & $\mathrm{ug} / \mathrm{L}$ & 70.00 & 480.00 & 200.91 & 159.90 & 79.59 \\
\hline $\mathrm{Zn}$ & $\mathrm{ug} / \mathrm{L}$ & 1.90 & 49.30 & 18.30 & 14.32 & 78.26 \\
\hline As & $\mathrm{ug} / \mathrm{L}$ & 0.90 & 91.60 & 11.49 & 26.74 & 232.75 \\
\hline $\mathrm{Pb}$ & $\mathrm{ug} / \mathrm{L}$ & 0.80 & 11.10 & 3.89 & 2.95 & 75.76 \\
\hline $\mathrm{Cd}$ & ug/L & 0.00 & 0.20 & 0.03 & 0.06 & 237.11 \\
\hline
\end{tabular}


Table 7. Continued.

\begin{tabular}{|c|c|c|c|c|c|c|}
\hline T-Cr & ug/L & 0.60 & 17.90 & 6.79 & 6.11 & 90.02 \\
\hline $\mathrm{Al}$ & $\mathrm{ug} / \mathrm{L}$ & 121.20 & 3430.00 & 1081.95 & 1099.45 & 101.62 \\
\hline $\mathrm{I}-$ & $\mathrm{ug} / \mathrm{L}$ & 0.00 & 71.00 & 11.91 & 19.95 & 167.54 \\
\hline $\mathrm{Fe}$ & $\mathrm{ug} / \mathrm{L}$ & 130.00 & 2340.00 & 1120.91 & 703.38 & 62.75 \\
\hline $\mathrm{DBS}$ & $\mathrm{ug} / \mathrm{L}$ & 14.00 & 39.00 & 24.86 & 8.57 & 34.46 \\
\hline
\end{tabular}

Table 8. Statistics of the measured parameters for the collected groundwater samples of four aquifer sub-areas, I, II, III, IV.

\begin{tabular}{|c|c|c|c|c|c|c|}
\hline I-Parameters & Unit & Minimum & Maximum & Mean & Std. Deviation & Coefficient of variation( $\%)$ \\
\hline Water temper $\left({ }^{\circ} \mathrm{C}\right)$ & $\left({ }^{\circ} \mathrm{C}\right)$ & 8.50 & 12.60 & 11.03 & 1.18 & 10.67 \\
\hline $\mathrm{PH}$ & _ & 6.80 & 7.39 & 7.12 & 0.23 & 3.26 \\
\hline Turbidity & NTU & 0.40 & 2.70 & 1.95 & 0.73 & 37.68 \\
\hline $\mathrm{EC}$ & $\mathrm{us} / \mathrm{cm}$ & 309.00 & 1826.00 & 961.13 & 604.74 & 62.92 \\
\hline Eh & $\mathrm{mv}$ & -36.50 & 204.50 & 109.44 & 81.62 & 74.58 \\
\hline DO & $\mathrm{mg} / \mathrm{L}$ & 3.60 & 9.02 & 5.90 & 2.08 & 35.25 \\
\hline $\mathrm{TH}$ & $\mathrm{mg} / \mathrm{L}$ & 135.92 & 563.11 & 322.33 & 124.65 & 38.67 \\
\hline TDS & $\mathrm{mg} / \mathrm{L}$ & 306.00 & 957.00 & 604.38 & 192.68 & 31.88 \\
\hline $\mathrm{Ca}^{2+}$ & $\mathrm{mg} / \mathrm{L}$ & 41.99 & 205.29 & 93.51 & 49.44 & 52.87 \\
\hline $\mathrm{Mg}^{2+}$ & $\mathrm{mg} / \mathrm{L}$ & 7.55 & 51.90 & 21.59 & 15.36 & 71.16 \\
\hline $\mathrm{K}^{+}$ & $\mathrm{mg} / \mathrm{L}$ & 0.55 & 3.14 & 1.56 & 0.86 & 55.48 \\
\hline $\mathrm{Na}^{+}$ & $\mathrm{mg} / \mathrm{L}$ & 14.22 & 53.27 & 32.34 & 13.82 & 42.75 \\
\hline $\mathrm{Cl}^{-}$ & $\mathrm{mg} / \mathrm{L}$ & 7.09 & 186.12 & 98.82 & 71.47 & 72.32 \\
\hline $\mathrm{SO}_{4}^{2-}$ & $\mathrm{mg} / \mathrm{L}$ & 0.00 & 167.42 & 35.38 & 55.64 & 157.29 \\
\hline $\mathrm{HCO}_{3}^{-}$ & $\mathrm{mg} / \mathrm{L}$ & 191.64 & 371.66 & 271.49 & 68.97 & 25.41 \\
\hline $\mathrm{NO}_{3}^{-}$ & $\mathrm{mg} / \mathrm{L}$ & 0.00 & 110.00 & 20.00 & 36.94 & 184.68 \\
\hline $\mathrm{NO}_{2}^{-}$ & $\mathrm{mg} / \mathrm{L}$ & 0.00 & 0.60 & 0.16 & 0.20 & 128.37 \\
\hline $\mathrm{F}^{-}$ & $\mathrm{mg} / \mathrm{L}$ & 0.26 & 0.57 & 0.41 & 0.10 & 25.52 \\
\hline $\mathrm{SiO}_{2}$ & $\mathrm{mg} / \mathrm{L}$ & 24.70 & 53.29 & 34.06 & 9.65 & 28.34 \\
\hline CODmn & $\mathrm{mg} / \mathrm{L}$ & 1.30 & 18.60 & 4.80 & 5.73 & 119.30 \\
\hline $\mathrm{Cu}$ & $\mathrm{ug} / \mathrm{L}$ & 0.00 & 3610.00 & 1030.00 & 1148.58 & 111.51 \\
\hline $\mathrm{Mn}$ & $\mathrm{ug} / \mathrm{L}$ & 3.20 & 33.70 & 16.44 & 10.00 & 60.85 \\
\hline $\mathrm{Zn}$ & $\mathrm{ug} / \mathrm{L}$ & 0.70 & 24.20 & 8.99 & 8.73 & 97.09 \\
\hline As & $\mathrm{ug} / \mathrm{L}$ & 0.00 & 4.60 & 1.89 & 1.59 & 84.03 \\
\hline $\mathrm{Pb}$ & $\mathrm{ug} / \mathrm{L}$ & 1.90 & 6.70 & 3.74 & 1.56 & 41.87 \\
\hline $\mathrm{T}-\mathrm{Cr}$ & $\mathrm{ug} / \mathrm{L}$ & 126.40 & 1111.00 & 299.54 & 333.49 & 111.33 \\
\hline $\mathrm{Al}$ & $\mathrm{ug} / \mathrm{L}$ & 2.00 & 14.00 & 6.63 & 3.54 & 53.48 \\
\hline $\mathrm{I}^{-}$ & $\mathrm{ug} / \mathrm{L}$ & 70.00 & 3580.00 & 1478.75 & 1371.27 & 92.73 \\
\hline $\mathrm{Fe}$ & $\mathrm{ug} / \mathrm{L}$ & 14.30 & 29.80 & 22.99 & 5.67 & 24.65 \\
\hline DBS & $\mathrm{ug} / \mathrm{L}$ & 0.65 & 3.31 & 1.46 & 0.81 & 55.32 \\
\hline
\end{tabular}


Table 8. Continued.

\begin{tabular}{|c|c|c|c|c|c|c|}
\hline II-Parameters & Unit & Minimum & Maximum & Mean & Std.Deviation & coefficient of variation( $\%)$ \\
\hline Water temper $\left({ }^{\circ} \mathrm{C}\right)$ & $\left({ }^{\circ} \mathrm{C}\right)$ & 6.90 & 8.30 & 7.94 & 0.50 & 6.28 \\
\hline $\mathrm{PH}$ & _ & 7.07 & 8.10 & 7.55 & 0.42 & 5.55 \\
\hline Turbidity & NTU & 1.90 & 13.10 & 7.16 & 3.71 & 51.80 \\
\hline $\mathrm{EC}$ & $\mathrm{us} / \mathrm{cm}$ & 377.00 & 1715.00 & 584.38 & 458.55 & 78.47 \\
\hline Eh & $\mathrm{mv}$ & 11.60 & 185.10 & 116.54 & 67.11 & 57.59 \\
\hline DO & $\mathrm{mg} / \mathrm{L}$ & 2.15 & 41.85 & 11.93 & 13.89 & 116.49 \\
\hline $\mathrm{TH}$ & $\mathrm{mg} / \mathrm{L}$ & 126.82 & 222.38 & 198.70 & 32.66 & 16.44 \\
\hline TDS & $\mathrm{mg} / \mathrm{L}$ & 299.00 & 454.00 & 387.00 & 50.83 & 13.14 \\
\hline $\mathrm{Ca} 2+$ & $\mathrm{mg} / \mathrm{L}$ & 46.03 & 79.45 & 63.44 & 13.00 & 20.49 \\
\hline $\mathrm{Mg} 2+$ & $\mathrm{mg} / \mathrm{L}$ & 2.48 & 22.43 & 9.87 & 7.28 & 73.75 \\
\hline $\mathrm{K}+$ & $\mathrm{mg} / \mathrm{L}$ & 0.58 & 2.26 & 1.39 & 0.69 & 49.43 \\
\hline $\mathrm{Na}+$ & $\mathrm{mg} / \mathrm{L}$ & 7.76 & 12.66 & 9.80 & 1.67 & 17.08 \\
\hline $\mathrm{Cl}-$ & $\mathrm{mg} / \mathrm{L}$ & 1.77 & 10.55 & 5.52 & 2.55 & 46.26 \\
\hline SO42- & $\mathrm{mg} / \mathrm{L}$ & 0.00 & 11.41 & 3.63 & 4.87 & 134.19 \\
\hline $\mathrm{HCO} 3-$ & $\mathrm{mg} / \mathrm{L}$ & 177.88 & 312.93 & 245.40 & 46.48 & 18.94 \\
\hline NO3- & $\mathrm{mg} / \mathrm{L}$ & 1.00 & 30.00 & 11.38 & 11.73 & 103.16 \\
\hline NO2- & $\mathrm{mg} / \mathrm{L}$ & 0.00 & 0.04 & 0.01 & 0.01 & 194.26 \\
\hline F- & $\mathrm{mg} / \mathrm{L}$ & 0.34 & 0.86 & 0.58 & 0.16 & 26.95 \\
\hline $\mathrm{SiO} 2$ & $\mathrm{mg} / \mathrm{L}$ & 27.04 & 63.57 & 35.85 & 12.10 & 33.75 \\
\hline CODmn & $\mathrm{mg} / \mathrm{L}$ & 0.10 & 6.40 & 1.11 & 2.15 & 192.81 \\
\hline $\mathrm{Cu}$ & $\mathrm{ug} / \mathrm{L}$ & 0.00 & 770.00 & 305.00 & 302.18 & 99.08 \\
\hline $\mathrm{Mn}$ & $\mathrm{ug} / \mathrm{L}$ & 0.30 & 3.90 & 2.06 & 1.36 & 65.76 \\
\hline $\mathrm{Zn}$ & $\mathrm{ug} / \mathrm{L}$ & 0.00 & 47.60 & 10.00 & 16.57 & 165.73 \\
\hline As & $\mathrm{ug} / \mathrm{L}$ & 0.00 & 0.70 & 0.33 & 0.32 & 96.95 \\
\hline $\mathrm{Pb}$ & $\mathrm{ug} / \mathrm{L}$ & 0.00 & 5.00 & 1.53 & 1.96 & 128.72 \\
\hline $\mathrm{T}-\mathrm{Cr}$ & $\mathrm{ug} / \mathrm{L}$ & 0.00 & 14.90 & 4.86 & 5.09 & 104.62 \\
\hline $\mathrm{Al}$ & $\mathrm{ug} / \mathrm{L}$ & 0.00 & 18.00 & 4.13 & 6.56 & 158.94 \\
\hline I- & $\mathrm{ug} / \mathrm{L}$ & 20.00 & 2130.00 & 665.00 & 817.40 & 122.92 \\
\hline $\mathrm{Fe}$ & $\mathrm{ug} / \mathrm{L}$ & 9.00 & 46.00 & 20.50 & 11.55 & 56.35 \\
\hline DBS & $\mathrm{ug} / \mathrm{L}$ & 0.24 & 1.06 & 0.60 & 0.28 & 46.93 \\
\hline III-Parameters & Unit & Minimum & Maximum & Mean & Std.Deviation & Coefficient of variation( $(\%)$ \\
\hline Water temper $\left({ }^{\circ} \mathrm{C}\right)$ & $\left({ }^{\circ} \mathrm{C}\right)$ & 8.50 & 25.40 & 12.38 & 3.81 & 30.79 \\
\hline $\mathrm{PH}$ & - & 6.55 & 8.59 & 7.65 & 0.55 & 7.22 \\
\hline Turbidity & NTU & 0.20 & 195.00 & 3.09 & 37.75 & 1222.67 \\
\hline $\mathrm{EC}$ & $\mathrm{us} / \mathrm{cm}$ & 3.51 & 2360.00 & 1012.38 & 529.65 & 52.32 \\
\hline Eh & $\mathrm{mv}$ & -62.20 & 1116.00 & 152.65 & 224.35 & 146.97 \\
\hline DO & $\mathrm{mg} / \mathrm{L}$ & 3.30 & 10.89 & 8.20 & 2.24 & 27.26 \\
\hline $\mathrm{TH}$ & $\mathrm{mg} / \mathrm{L}$ & 58.25 & 978.64 & 349.52 & 184.32 & 52.74 \\
\hline TDS & $\mathrm{mg} / \mathrm{L}$ & 155.00 & 1892.00 & 773.75 & 347.13 & 44.86 \\
\hline
\end{tabular}


Table 8. Continued.

\begin{tabular}{|c|c|c|c|c|c|c|}
\hline $\mathrm{Ca} 2+$ & $\mathrm{mg} / \mathrm{L}$ & 18.66 & 172.63 & 84.57 & 38.33 & 45.33 \\
\hline $\mathrm{Mg} 2+$ & $\mathrm{mg} / \mathrm{L}$ & 2.83 & 196.27 & 33.99 & 37.91 & 111.54 \\
\hline $\mathrm{K}+$ & $\mathrm{mg} / \mathrm{L}$ & 0.26 & 2.80 & 0.82 & 0.66 & 79.87 \\
\hline $\mathrm{Na}+$ & $\mathrm{mg} / \mathrm{L}$ & 8.15 & 161.30 & 54.35 & 42.33 & 77.89 \\
\hline $\mathrm{Cl}-$ & $\mathrm{mg} / \mathrm{L}$ & 3.55 & 248.16 & 39.77 & 60.48 & 152.07 \\
\hline SO42- & $\mathrm{mg} / \mathrm{L}$ & 0.00 & 846.07 & 143.03 & 169.68 & 118.63 \\
\hline HCO3- & $\mathrm{mg} / \mathrm{L}$ & 63.88 & 569.11 & 322.66 & 129.59 & 40.16 \\
\hline NO3- & $\mathrm{mg} / \mathrm{L}$ & 3.00 & 100.00 & 35.63 & 24.75 & 69.46 \\
\hline NO2- & $\mathrm{mg} / \mathrm{L}$ & 0.00 & 0.04 & 0.00 & 0.01 & 227.10 \\
\hline F- & $\mathrm{mg} / \mathrm{L}$ & 0.28 & 1.56 & 0.76 & 0.30 & 39.97 \\
\hline $\mathrm{SiO} 2$ & $\mathrm{mg} / \mathrm{L}$ & 15.57 & 67.99 & 25.04 & 12.74 & 50.87 \\
\hline CODmn & $\mathrm{mg} / \mathrm{L}$ & 0.50 & 7.70 & 3.20 & 2.17 & 67.73 \\
\hline $\mathrm{Cu}$ & $\mathrm{ug} / \mathrm{L}$ & 0.00 & 2760.00 & 307.50 & 675.36 & 219.63 \\
\hline $\mathrm{Mn}$ & ug/L & 4.50 & 1012.00 & 168.29 & 196.54 & 116.79 \\
\hline $\mathrm{Zn}$ & ug/L & 0.20 & 39.10 & 4.45 & 8.71 & 195.79 \\
\hline As & $\mathrm{ug} / \mathrm{L}$ & 0.70 & 13.60 & 4.48 & 2.95 & 65.97 \\
\hline $\mathrm{Pb}$ & ug/L & 0.90 & 12.80 & 3.48 & 3.00 & 86.33 \\
\hline $\mathrm{T}-\mathrm{Cr}$ & $\mathrm{ug} / \mathrm{L}$ & 70.10 & 1788.00 & 363.35 & 326.45 & 89.85 \\
\hline $\mathrm{Al}$ & ug/L & 0.00 & 21.00 & 5.63 & 5.52 & 98.05 \\
\hline I- & ug/L & 20.00 & 12210.00 & 778.75 & 3017.30 & 387.45 \\
\hline $\mathrm{Fe}$ & $\mathrm{ug} / \mathrm{L}$ & 14.10 & 33.70 & 21.86 & 5.52 & 25.25 \\
\hline DBS & ug/L & 0.56 & 2.18 & 0.81 & 0.39 & 48.24 \\
\hline IV-Parameters & Unit & Minimum & Maximum & Mean & Std. Deviation & Coefficient of variation( $\%)$ \\
\hline Water temper $\left({ }^{\circ} \mathrm{C}\right)$ & $\left({ }^{\circ} \mathrm{C}\right)$ & 6.10 & 12.40 & 8.81 & 1.56 & 17.75 \\
\hline $\mathrm{PH}$ & - & 7.26 & 9.07 & 7.97 & 0.46 & 5.77 \\
\hline Turbidity & NTU & 1.30 & 93.70 & 15.39 & 16.73 & 108.74 \\
\hline $\mathrm{EC}$ & $\mathrm{us} / \mathrm{cm}$ & 3.36 & 2194.00 & 747.06 & 509.08 & 68.14 \\
\hline Eh & $\mathrm{mv}$ & -152.80 & 184.20 & 48.73 & 97.65 & 200.38 \\
\hline DO & $\mathrm{mg} / \mathrm{L}$ & 2.03 & 36.50 & 8.88 & 8.09 & 91.11 \\
\hline $\mathrm{TH}$ & $\mathrm{mg} / \mathrm{L}$ & 136.85 & 504.18 & 269.11 & 84.36 & 31.35 \\
\hline TDS & $\mathrm{mg} / \mathrm{L}$ & 327.00 & 2107.00 & 675.41 & 385.58 & 57.09 \\
\hline $\mathrm{Ca} 2+$ & $\mathrm{mg} / \mathrm{L}$ & 20.63 & 137.05 & 65.85 & 23.89 & 36.28 \\
\hline $\mathrm{Mg} 2+$ & $\mathrm{mg} / \mathrm{L}$ & 4.01 & 71.20 & 25.31 & 15.73 & 62.16 \\
\hline $\mathrm{K}+$ & $\mathrm{mg} / \mathrm{L}$ & 0.36 & 2.80 & 1.31 & 0.76 & 58.08 \\
\hline $\mathrm{Na}+$ & $\mathrm{mg} / \mathrm{L}$ & 6.19 & 508.50 & 75.01 & 104.49 & 139.31 \\
\hline $\mathrm{Cl}-$ & $\mathrm{mg} / \mathrm{L}$ & 3.55 & 319.05 & 51.87 & 66.79 & 128.74 \\
\hline SO42- & $\mathrm{mg} / \mathrm{L}$ & 0.00 & 378.67 & 40.16 & 71.00 & 176.78 \\
\hline HCO3- & $\mathrm{mg} / \mathrm{L}$ & 204.23 & 1083.73 & 384.14 & 166.88 & 43.44 \\
\hline NO3- & $\mathrm{mg} / \mathrm{L}$ & 0.00 & 50.00 & 9.38 & 13.68 & 145.76 \\
\hline NO2- & $\mathrm{mg} / \mathrm{L}$ & 0.00 & 0.20 & 0.01 & 0.04 & 289.81 \\
\hline
\end{tabular}


Table 8. Continued.

\begin{tabular}{|c|c|c|c|c|c|c|}
\hline $\mathrm{F}-$ & $\mathrm{mg} / \mathrm{L}$ & 0.34 & 8.49 & 1.34 & 1.43 & 106.02 \\
\hline $\mathrm{SiO} 2$ & $\mathrm{mg} / \mathrm{L}$ & 10.69 & 55.28 & 27.82 & 12.81 & 46.05 \\
\hline $\mathrm{CODmn}$ & $\mathrm{mg} / \mathrm{L}$ & 0.00 & 33.40 & 3.02 & 7.30 & 184.89 \\
\hline $\mathrm{Cu}$ & $\mathrm{ug} / \mathrm{L}$ & 0.00 & 7840.00 & 819.12 & 1514.42 & 184.63 \\
\hline $\mathrm{Mn}$ & $\mathrm{ug} / \mathrm{L}$ & 0.00 & 73.80 & 7.07 & 13.05 & 184.76 \\
\hline $\mathrm{Zn}$ & $\mathrm{ug} / \mathrm{L}$ & 0.00 & 78.20 & 8.83 & 16.32 & 172.44 \\
\hline $\mathrm{As}$ & $\mathrm{ug} / \mathrm{L}$ & 0.00 & 5.30 & 0.68 & 1.18 & 185.12 \\
\hline $\mathrm{Pb}$ & $\mathrm{ug} / \mathrm{L}$ & 0.00 & 18.20 & 1.92 & 3.56 & 244.90 \\
\hline $\mathrm{T}-\mathrm{Cr}$ & $\mathrm{ug} / \mathrm{L}$ & 0.40 & 401.60 & 33.48 & 81.98 & 174.60 \\
\hline $\mathrm{Al}$ & $\mathrm{ug} / \mathrm{L}$ & 0.00 & 92.00 & 13.09 & 22.85 & 258.99 \\
\hline $\mathrm{I}-$ & $\mathrm{ug} / \mathrm{L}$ & 10.00 & 48930.00 & 4807.65 & 12451.21 & 38.66 \\
\hline $\mathrm{Fe}$ & $\mathrm{ug} / \mathrm{L}$ & 10.00 & 49.90 & 24.96 & 9.65 & 63.65 \\
\hline $\mathrm{DBS}$ & $\mathrm{ug} / \mathrm{L}$ & 0.25 & 3.28 & 1.18 & 0.75 & \\
\hline
\end{tabular}

Table 9. Isotopic compositions of water samples collected in the Second Songhua River Basin.

\begin{tabular}{|c|c|c|c|c|}
\hline & ID & Sample ID & Processed Delta 2H/\%o & Processed Delta 180/\%o \\
\hline \multirow{14}{*}{ Groundwater samples } & 1 & DX1 & -71.57 & -9.52 \\
\hline & 2 & DX2 & -75.29 & -10.12 \\
\hline & 3 & DX3 & -72.45 & -9.48 \\
\hline & 4 & DX4 & -77.5 & -10.37 \\
\hline & 8 & DXJJ & -71.06 & -9.56 \\
\hline & 9 & DXSHJ & -72.92 & -9.87 \\
\hline & 10 & DXQY & -72.14 & -9.63 \\
\hline & 11 & ES16 & -74.4 & -10.5 \\
\hline & 12 & ES14 & -71.5 & -9.8 \\
\hline & 13 & ES12 & -74.4 & -10.5 \\
\hline & 14 & ES10 & -75.1 & -10.4 \\
\hline & 15 & ES08 & -72.8 & -9.9 \\
\hline & 16 & ES02 & -73.8 & -10.2 \\
\hline & 17 & ES05 & -69.3 & -9.3 \\
\hline \multirow{11}{*}{ Surface water samples } & 18 & DBP3 & -81.98 & -11.36 \\
\hline & 19 & DBQY & -70.76 & -9.1 \\
\hline & 20 & DBSHJ & -81.91 & -11.39 \\
\hline & 21 & DBJJ & -51.63 & -5.44 \\
\hline & 22 & ES15 & -81.8 & -11.8 \\
\hline & 23 & ES13 & -81.6 & -11.7 \\
\hline & 24 & ES11 & -81.3 & -11.5 \\
\hline & 25 & ES07 & -80 & -11.2 \\
\hline & 26 & ES04 & -63.3 & -8.2 \\
\hline & 27 & ES06 & -65.1 & -8.5 \\
\hline & 28 & ES03 & -59 & -7.2 \\
\hline
\end{tabular}


Table 10. Results of factor analysis after varimaxa rotation for surface water.

\begin{tabular}{|c|c|c|c|c|c|}
\hline \multirow{2}{*}{ Indicators } & \multicolumn{5}{|c|}{ Factors } \\
\hline & 1 & 2 & 3 & 4 & 5 \\
\hline $\mathrm{Ca}^{2+}$ & .754 & .459 & .085 & .107 & -.386 \\
\hline $\mathrm{Mg}^{2+}$ & -.029 & .445 & -.368 & -.635 & .051 \\
\hline $\mathrm{K}$ & .967 & -.222 & -.101 & .014 & .038 \\
\hline $\mathrm{Na}$ & .966 & -.240 & -.041 & -.026 & .050 \\
\hline $\mathrm{Cl}$ & .966 & -.234 & -.061 & -.017 & .052 \\
\hline $\mathrm{SO}_{4}^{2-}$ & .941 & .077 & -.043 & .109 & .051 \\
\hline $\mathrm{HCO}_{3}^{-}$ & .984 & -.140 & -.012 & -.062 & -.058 \\
\hline $\mathrm{NO}_{3}^{-}$ & -.240 & -.027 & .443 & .515 & .643 \\
\hline $\mathrm{NO}_{2}^{-}$ & .114 & .667 & .053 & .561 & -.375 \\
\hline $\mathrm{F}$ & .952 & .026 & .117 & -.155 & -.118 \\
\hline $\mathrm{S}_{\mathrm{i}} \mathrm{O}_{2}$ & .602 & -.549 & .159 & .462 & .049 \\
\hline $\mathrm{Cu}$ & .970 & -.080 & .031 & -.066 & .006 \\
\hline $\mathrm{Mn}$ & .151 & .765 & -.288 & .043 & .043 \\
\hline $\mathrm{Zn}$ & .384 & .689 & .486 & .296 & -.029 \\
\hline As & .978 & -.193 & -.040 & -.015 & .025 \\
\hline $\mathrm{Pb}$ & .018 & .848 & .066 & .414 & -.119 \\
\hline $\mathrm{TCr}$ & .136 & .567 & .584 & -.375 & .244 \\
\hline $\mathrm{Al}$ & .334 & .805 & -.364 & .003 & .243 \\
\hline I & .971 & -.187 & -.066 & -.114 & .017 \\
\hline $\mathrm{Fe}$ & .214 & .748 & .306 & -.335 & .251 \\
\hline DBS & .384 & -.466 & -.437 & .259 & .527 \\
\hline CODmn & .968 & -.241 & -.013 & -.012 & .042 \\
\hline Eigenvalue & 11.397 & 7.092 & 2.364 & 1.942 & 1.313 \\
\hline$\%$ of variance & 43.836 & 27.278 & 9.091 & 7.470 & 5.049 \\
\hline Cumulative $\%$ & 43.836 & 71.114 & 80.205 & 87.675 & 92.724 \\
\hline
\end{tabular}

Extraction method: principal component analysis (PCA)

Rotation method: orthogonal rotation method with Kaiser standardization.

a: Rotation converges after the 9 iteration.

Table 11. Results of factor analysis after varimaxa rotation for groundwater.

\begin{tabular}{|c|c|c|c|c|c|c|c|c|}
\hline & \multicolumn{8}{|c|}{ Factors } \\
\hline & 1 & 2 & 3 & 4 & 5 & 6 & 7 & 8 \\
\hline $\mathrm{Ca}^{2+}$ & -.132 & .064 & .098 & -.077 & .853 & .028 & .027 & .032 \\
\hline $\mathrm{Mg}^{2+}$ & .264 & -.007 & .860 & .089 & -.062 & .068 & .075 & -.043 \\
\hline $\mathrm{K}$ & -.076 & .636 & .150 & -.194 & .096 & .429 & -.212 & -.068 \\
\hline $\mathrm{Na}$ & .701 & .142 & .505 & .051 & .149 & .105 & .076 & -.110 \\
\hline $\mathrm{Cl}$ & .265 & .228 & .312 & .124 & .619 & .228 & .191 & -.234 \\
\hline $\mathrm{SO}_{4}^{2-}$ & .006 & -.022 & .929 & .080 & .171 & -.057 & .020 & -.035 \\
\hline $\mathrm{HCO}_{3}$ & .817 & .145 & .382 & -.088 & .028 & .122 & .014 & .036 \\
\hline $\mathrm{NO}_{3}^{-}$ & .006 & -.196 & -.080 & .113 & .744 & -.082 & -.127 & .290 \\
\hline $\mathrm{NO}_{2}^{-}$ & -.033 & -.141 & -.169 & .159 & .071 & .716 & -.023 & -.184 \\
\hline $\mathrm{F}$ & .875 & -.168 & .023 & -.076 & -.100 & .000 & .026 & .142 \\
\hline
\end{tabular}


Table 11. Continued.

\begin{tabular}{|c|c|c|c|c|c|c|c|c|}
\hline $\mathrm{SiO}_{2}$ & -.366 & .438 & -.136 & .087 & -.102 & .044 & -.468 & -.176 \\
\hline $\mathrm{Cu}$ & .046 & .055 & .343 & .148 & .052 & .490 & .551 & .112 \\
\hline $\mathrm{Mn}$ & .039 & .915 & .014 & .101 & .004 & .050 & -.026 & -.002 \\
\hline $\mathrm{Zn}$ & .006 & -.056 & -.083 & .085 & .139 & -.088 & .073 & .836 \\
\hline $\mathrm{As}$ & -.084 & .264 & .101 & -.088 & -.299 & .412 & -.340 & .293 \\
\hline $\mathrm{Pb}$ & -.092 & .071 & .062 & .791 & -.108 & .027 & -.028 & .213 \\
\hline $\mathrm{TCr}$ & .156 & -.160 & .105 & .689 & .284 & .009 & .093 & -.129 \\
\hline $\mathrm{Al}$ & -.080 & .086 & .029 & .861 & -.012 & .048 & .111 & -.014 \\
\hline $\mathrm{I}$ & .815 & -.011 & -.087 & .054 & -.021 & -.064 & .006 & -.121 \\
\hline $\mathrm{Fe}$ & .003 & .902 & -.060 & .024 & -.040 & -.115 & -.083 & -.010 \\
\hline DBS & -.022 & -.137 & .000 & .106 & -.051 & -.076 & .858 & .000 \\
\hline $\mathrm{COD}$ & .255 & .420 & .226 & -.105 & -.035 & .575 & .028 & .028 \\
\hline Eigenvalue & 4.169 & 3.226 & 2.402 & 1.763 & 1.468 & 1.217 & 1.077 & 1.049 \\
\hline \% of variance & 18.948 & 14.662 & 10.919 & 8.013 & 6.674 & 5.530 & 4.897 & 4.768 \\
\hline Cumulative \% & 18.948 & 33.610 & 44.529 & 52.542 & 59.216 & 64.746 & 69.643 & 74.411 \\
\hline
\end{tabular}

Extraction method: principal component analysis (PCA).

Rotation method: orthogonal rotation method with Kaiser standardization.

a: Rotation converges after the 9 iteration.

and RSC indicators can be used to estimate the amount of $\mathrm{Na}^{+}$adsorbed by soil and the amount of $\mathrm{HCO}_{3}{ }^{-}$and $\mathrm{CO}_{3}^{2-}$ that can be combined with $\mathrm{Na}^{+}$in the water. That is to say, if water with both indicators higher than the standard limit is used as irrigation water, the risk of salt and alkaline soil formation is increased. Based on the above analysis, combined with the SSP, KR, and MAR calculation results, if the Second Songhua River Basin downstream water (including both the surface water and groundwater) is used as irrigation water, the saline soil and saline-alkali soil will easily be produced. That is, the downstream water body is not suitable as irrigation water. Under the background of the connecting project of the West River and lake in Jilin, and the greatly increasing irrigation area, it is necessary to use certain treatment measures for the water before it is used for irrigation. Otherwise, salinization of the soil will occur, which will affect the crop yields and damage the state of the environment.

\section{Conclusions}

Based on the above research, the following three conclusions are drawn:

1. The research of isotope content indicated that the groundwater recharge source was relatively stable. The surface water received atmospheric precipitation and groundwater recharge, while groundwater was recharged by atmospheric precipitation. The overall environment of the area was alkaline. A total of
$92 \%$ of the surface water and groundwater TDS was less than $1 \mathrm{~g}$ per liter, making it weak mineralized water. The dominant water types of the surface and groundwater were $\mathrm{Ca}-\mathrm{HCO}_{3}$ and $\mathrm{Ca}-\mathrm{Mg}-\mathrm{HCO}_{3}$.

2. The Gibbs plot, CAI-1 index, and Varimax rotated factor loading for the water showed that silicate weathering, carbonate mineral dissolution, and the ion exchange process controlled the hydro-chemistry compositions. The high $\mathrm{NO}_{2}^{-}$score and the middle DBS score showed that the water body has begun to be contaminated by agriculture, and was also affected by domestic sewage.

3. The indicator calculation results of the SSP, MAR and KR showed that the surface water and groundwater in the study area could be used for irrigation, while the water downstream of the basin may accelerate the formation of alkaline and saline soil if used for irrigation. Under the background of the connecting project of the West River and lake in Jilin, and the greatly increasing irrigation area, it is necessary to use certain treatment measures for the downstream water before it is used for irrigation. Otherwise, salinization of the soil will be caused, which will affect crop yields and damage the state of the environment.

\section{Acknowledgements}

This research was funded by the National Key R\&D Program lof China, grant number 2018YFC1800400. 
Supported by National Natural Science Foundation of China $(41072255,41807155)$ and Natural Science Foundation of Jilin Province (20150101116JC). The authors acknowledge the laboratory of the Heilongjiang Province Hydrogeology and Environmental Geology Investigation Institute and the Laboratory of Geographical Resources Institute of Geographic Sciences and Natural Resources Research, CAS for element analysis of the water samples. Supported by the 111 project, No. B16020. We also appreciate valuable suggestions from the editor and anonymous reviewers for improving the manuscript.

\section{Conflict of Interest}

The authors declare no conflict of interest.

\section{References}

1. FARID., INTISSAR., TRABELSI., RIM., ZOUARI., KAMEL., BEJI., RIDH A. Geochemical and isotopic study of surface and groundwaters in Ain Bou Mourra basin, central Tunisia . Quaternary International. 303, 210, 2013.

2. YANG G., HE X.L., LI X.L., LONG A.H., XUE L.Q. Transformation of surface water and groundwater and water balance in the agricultural irrigation area of the Manas River Basin, China . International Journal of Agricultural and Biological Engineering. 10 (4), 107, 2017.

3. HUANG L.H., LIANG Z.W., SUAREZ D.L., WANG Z.C., WANG M.M., YANG H.Y., LIU M. Impact of cultivation year, nitrogen fertilization rate and irrigation water quality on soil salinity and soil nitrogen in saline-sodic paddy fields in Northeast China . Journal of Agricultural Science. 154 (4), 632, 2016.

4. LUO J.M., YANG F., WANG Y.J., YA Y.J., DENG W., ZHANG X.P., LIU Z. Mechanism of Soil Sodification at the Local Scale in Songnen Plain, Northeast China, as Affected by Shallow Groundwater Table . Arid Land Research and Management. 25 (3), 234, 2011.

5. KOVAC S., KEN T., DURAND M., ALVAR O. The influence of on-and off farm surface water investment on groundwater extaction from an agricultural landscape. Journal of Agricultural and Applied Economics. 49 (3), 323, 2017.

6. TAYLOR., SARAH A., GAZIS., CAREY A. A geochemical study of the impact of irrigation and aquifer lithology on groundwater in the Upper Yakima River Basin, Washington, USA . Environmental Earth Sciences. 72 (5), 1569, 2014.

7. MAGAI S., D.VYSHPOLSKII F.F. Combined Use of Surface and Subsurface Waters in the Irrigated ArysTurkestan Massif in Southern Kazakhstan. Water Resources. 42 (1), 116, 2015.

8. WINTER T.C. Ground water and surface water, A single resource. US Geological Survey. 1999.

9. WILSON J., ROCHA C.A combined remote sensing and multi-tracer approach for localising and assessing groundwater-lake interactions. International Journal of Applied Earth Observation and Geoinformation. 44, 195, 2016.
10. SHAH T. Towards a managed aquifer recharge strategy for Gujarat, India, An economist's dialogue with hydrogeologists. Journal of Hydrology. 518, 94, .2014.

11. SCHOUPS G., HOPMANS J.W., YOUNG C.A., VRUGT J.A., WALLENDER W.W., TANJI K.K., PANANDAY S. Sustainability of irrigated agriculture in the San Joaquin Valley, California. Proceedings of the National Academy of Sciences. 102, 15352, 2005.

12. GHASSEMI F., WJITE I. Inter-basin water transfer, Case studies from Australia, United States, Canada, China, and India. Cambridge,Cambridge University Press. 2007.

13. WANG R., BIAN J.M., GAO Y. Research on hydrochemical spatio-temporal characteristics of groundwater quality of different aquifer systems in Songhua River Basin, eastern Songnen Plain, Northeast China. Arabian Journal of Geosciences. 7 (12), 5081, 2014.

14. YANG F., ZHANG G.X., YIN X.R., LIU Z.J., HUANG Z.G. Study on capillary rise from shallow groundwater and critical water table depth of a saline-sodic soil in western Songnen plain of China. Environmental Earth Sciences. 64 (8), 2119, 2011

15. ZHAI Y.Z., ZHAO X.B.,TENG Y.G., LI X., ZHANG J.J., WU J., ZUO R.Groundwater nitrate pollution and human health risk assessment by using HHRA model in an agricultural area, NE China . Ecotoxicology and Environmental Safety. 137, 130, 2017.

16. HANG B., SONG, X.F., ZHANG Y.H., HAN D.M., TANG C.Y., YANG L.H., WANG Z.L. The relationship between and evolution of surface water and groundwater in Songnen Plain, Northeast China. Environmental Earth Sciences. 73 (12), 8333, 2015.

17. ZHANG B., SONG, X.F., ZHANG Y.H., HAN D.M., TANG C.Y.,YANG L.H., WANG Z.L. The renew ability and quality of shallow groundwater in Sanjiang and Songnen Plain, Northeast China. Journal of Integrative Agriculture. 16 (1), 229, 2017.

18. ZHANG B., SONG X.F., YING H., HAN D.M. TANG C.Y., YU YL., MA Y. Hydrochemical characteristics and water quality assessment of surface water and groundwater in Songnen plain, Northeast China. Water Research. 46 (8), 2737, 2012.

19. TODD DK. Groundwater hydrology. Wiley, New York. 10, 1980.

20. ALRAJHI A., BEECHAM S., BOLAN NS., HASSANHLI A. Evaluation of soil chemical properties irrigated with recycled wastewater under partial root-zone drying irrigation for sustainable tomato production. Agric Water Manag. 161, 127, 2015.

21. RAO N.S., SUBRAHMANYAM A., KUMAR S.R., SRINIVASULU N., RAO G.B., RAO P.S., REDY GV. Geochemistry and quality of groundwater of Gummanampadu sub-basin, Guntur District, Andhra Pradesh, India. Environ Earth Sci. 67 (5), 1451, 2012.

22. RAGUNATH HM. Groundwater. Wiley, New Delhi. 1987.

23. CJI CM., ZHAO CW., SUN XJ., WANG ZC. Estimating Exchangeable Sodium Percentage from Sodium Adsorption Ratio of Salt-Affected Soil in the Songnen Plain of Northeast China. Pedosphere. 21 (2), 271, 2011.

24. KELLEY WP. Use of saline irrigation water. Soil Sci. $\mathbf{9 5}$, $355,1963$.

25. WANG P., SONG X.F., HAN D.M., ZHANG Y.H., LIU $X$. A study of root water uptake of crops indicated by hydrogen and oxygen stable isotopes, A case in Shanxi Province, China. Agricultural Water Management. 97, 475, 2010. 
26. A.K.M. EDIAH., T.T. AKITI., S. OSAE D., ADOTEY., E.T. Glover. Hydrogeochemistry and isotope hydrology of surface water and groundwater systems in the Ellembelle district, Ghana, West Africa [J]. Appl Water Sci. 2017, (7), 609, 2017.

27. WEI W.C., ZONG Y. Identification of the origin of groundwater recharge using environmental isotopes of the southwest Songnen Plain .Journal of Arid Land Resources and Environment. 31 (01), 173, 2017.

28. DIDAR-U1 ISLAM., S. M.MAJMDER., RATAN KUMAR., UDDIN., MOHAMMED JAMAL., KHAIL., MDIBRAHIM., ALAM., MD FERDOUS. Hydrochemical Characteristics and Quality Assessment of Groundwater in Patuakhali District, Southern Coastal Region of Bangladesh .Exposure and Health. 9 (1), 43, 2017.

29. FAID., INTISSAR., ZOUARI., KAMEL., ABID., AYACHI., MOHAMED. Hydrogeochemical investigation of surface and groundwater composition in an irrigated land in Central Tunisia . Journal of African Earth Sciences. 78, 16, 2013
30. HASSEN., IMEN., HAMZAOUI-AZAZA., FADOUA., BOUHILA., RACHIDA.Application of multivariate statistical analysis and hydrochemical and isotopic investigations for evaluation of groundwater quality and its suitability for drinking and agriculture purposes, case of Oum Ali-Thelepte aquifer, central Tunisia .Environmental Monitoring and Assessment. 188 (3), 188, 2016.

31. BIAN JIANMIN., NIE SIYU, WANG YU. et al. Hydrochemical characteristics and quality assessment of groundwater for irrigation use in central and eastern Songnen Plain, Northeast China. Environ Monit Assess. 190 (2018), 381, 2018.

32. GIBBS RJ. Mechanisms controlling world water chemistry. Sci. 170, 795, 1970.

33. WILCOX LV. Classification and use of irrigation water. U.S. Department of Agriculture, Circular No. 969, Washington D.C. 1955.

34. DATTA PS., TYAGI SK. Major ion chemistry of groundwater in Delhi area, chemical weathering processes and groundwater flow regime. Geol Soc India. 47, 179, 1996. 
